\title{
Aerosol optical properties and direct radiative forcing based on measurements from the China Aerosol Remote Sensing Network (CARSNET) in eastern China
}

\author{
Huizheng Che ${ }^{1}$, Bing $\mathbf{Q i}^{2}$, Hujia Zhao ${ }^{1}$, Xiangao Xia ${ }^{3,4}$, Thomas F. Eck ${ }^{5}$, Philippe Goloub ${ }^{6}$, Oleg Dubovik ${ }^{6}$, \\ Victor Estelles $^{7}$, Emilio Cuevas-Agulló ${ }^{8}$, Luc Blarel ${ }^{6}$, Yunfei Wu ${ }^{9}$, Jun Zhu ${ }^{10}$, Rongguang Du ${ }^{2}$, Yaqiang Wang ${ }^{1}$, \\ Hong Wang ${ }^{1}$, Ke Gui ${ }^{1}$, Jie Yu ${ }^{1}$, Yu Zheng ${ }^{10}$, Tianze Sun ${ }^{1}$, Quanliang Chen ${ }^{11}$, Guangyu Shi ${ }^{12}$, and Xiaoye Zhang ${ }^{1}$ \\ ${ }^{1}$ State Key Laboratory of Severe Weather (LASW) and Institute of Atmospheric Composition, \\ Chinese Academy of Meteorological Sciences, CMA, Beijing 100081, China \\ ${ }^{2}$ Hangzhou Meteorological Bureau, Hangzhou, 310051, China \\ ${ }^{3}$ Laboratory for Middle Atmosphere and Global Environment Observation (LAGEO), Institute of Atmospheric Physics, \\ Chinese Academy of Sciences, Beijing 100029, China \\ ${ }^{4}$ School of Geoscience University of Chinese Academy of Science, Beijing 100049, China \\ ${ }^{5}$ Biospheric Sciences Branch, Code 923, NASA/Goddard Space Flight Center, Greenbelt, MD, USA \\ ${ }^{6}$ Laboratoire d'Optique Amosphérique, Université des Sciences et Technologies de Lille, 59655, Villeneuve d'Ascq, France \\ ${ }^{7}$ Dept. Fisica de la Terra i Termodinamica, Universitat de Valencia, C/ Dr. Moliner 50, 46100 Burjassot, Spain \\ ${ }^{8}$ Centro de Investigación Atmosférica de Izaña, AEMET, 38001 Santa Cruz de Tenerife, Spain \\ ${ }^{9}$ Key Laboratory of Regional Climate-Environment for Temperate East Asia, Institute of Atmospheric Physics, \\ Chinese Academy of Sciences, Beijing 100029, China \\ ${ }^{10}$ Collaborative Innovation Center on Forecast and Evaluation of Meteorological Disasters, Nanjing University of Information \\ Science \& Technology, Nanjing 210044, China \\ ${ }^{11}$ Plateau Atmospheric and Environment Key Laboratory of Sichuan Province, College of Atmospheric Sciences, \\ Chengdu University of Information Technology, Chengdu 610225, China \\ ${ }^{12}$ State Key Laboratory of Numerical Modeling for Atmospheric Sciences and Geophysical Fluid Dynamics (LASG), \\ Institute of Atmospheric Physics, Chinese Academy of Sciences, Beijing 100029, China
}

Correspondence: Huizheng Che (chehz@cma.gov.cn) and Xiaoye Zhang (xiaoye@cma.gov.cn)

Received: 7 June 2017 - Discussion started: 26 June 2017

Revised: 29 November 2017 - Accepted: 4 December 2017 - Published: 15 January 2018

\begin{abstract}
Aerosol pollution in eastern China is an unfortunate consequence of the region's rapid economic and industrial growth. Here, sun photometer measurements from seven sites in the Yangtze River Delta (YRD) from 2011 to 2015 were used to characterize the climatology of aerosol microphysical and optical properties, calculate direct aerosol radiative forcing (DARF) and classify the aerosols based on size and absorption. Bimodal size distributions were found throughout the year, but larger volumes and effective radii of fine-mode particles occurred in June and September due to hygroscopic growth and/or cloud processing. Increases in the fine-mode particles in June and September caused $\mathrm{AOD}_{440 \mathrm{~nm}}>1.00$ at most sites, and annual mean $\mathrm{AOD}_{440 \mathrm{~nm}}$
\end{abstract}

values of $0.71-0.76$ were found at the urban sites and 0.68 at the rural site. Unlike northern China, the $\mathrm{AOD}_{440 \mathrm{~nm}}$ was lower in July and August $(\sim 0.40-0.60)$ than in January and February (0.71-0.89) due to particle dispersion associated with subtropical anticyclones in summer. Low volumes and large bandwidths of both fine-mode and coarsemode aerosol size distributions occurred in July and August because of biomass burning. Single-scattering albedos at $440 \mathrm{~nm}\left(\mathrm{SSA}_{440 \mathrm{~nm}}\right)$ from 0.91 to 0.94 indicated particles with relatively strong to moderate absorption. Strongly absorbing particles from biomass burning with a significant SSA wavelength dependence were found in July and August at most sites, while coarse particles in March to May were 
mineral dust. Absorbing aerosols were distributed more or less homogeneously throughout the region with absorption aerosol optical depths at $440 \mathrm{~nm} \sim 0.04-0.06$, but inter-site differences in the absorption Angström exponent indicate a degree of spatial heterogeneity in particle composition. The annual mean DARF was $-93 \pm 44$ to $-79 \pm 39 \mathrm{~W} \mathrm{~m}^{-2}$ at the Earth's surface and $\sim-40 \mathrm{~W} \mathrm{~m}^{-2}$ at the top of the atmosphere (for the solar zenith angle range of 50 to $80^{\circ}$ ) under cloud-free conditions. The fine mode composed a major contribution of the absorbing particles in the classification scheme based on SSA, fine-mode fraction and extinction Angström exponent. This study contributes to our understanding of aerosols and regional climate/air quality, and the results will be useful for validating satellite retrievals and for improving climate models and remote sensing algorithms.

\section{Introduction}

Aerosols can have important effects on the Earth's climate over regional to global scales, but there are still uncertainties in the strengths and significance of these impacts (Hansen et al., 2000; Solomon et al., 2007; Schwartz and Andreae, 1996). Aerosols affect the radiative balance of the Earthatmosphere system by directly scattering and absorbing solar radiation (Charlson et al., 1992; Ackerman and Toon, 1981), and they can affect climate indirectly through aerosol-cloud interactions (Twomey et al., 1984; Albrecht, 1989; Z. Q. Li et al., 2016).

The physical and optical properties of aerosol particles determine their radiative effects, and information on these properties can be used to predict and assess global and regional changes in the Earth's climate (Eck et al., 2005; Myhre, 2009; IPCC, 2013; Panicker et al., 2013). Long-term, ground-based observations have contributed greatly to our understanding of the spatial variations in aerosols and their effects on the Earth's climate (Holben et al., 2001; Kaufman et al., 2002; Sanap and Pandithurai, 2014; Z. Q. Li et al., 2016). Ground-based monitoring networks have been established worldwide - for instance, AERONET (Aerosol Robotic Network) (Holben et al., 1998; Goloub et al., 2007), SKYNET (SKYrad Network) (Takamura and Nakajima, 2004), EARLINET (European aerosol Lidar network) (Pappalardo et al., 2014) and the GAW-PFR Network (Global Atmosphere Watch Programmer-Precision Filter Radiometers) (Wehrli, 2002; Estellés et al., 2012). In China, CARSNET (the China Aerosol Remote Sensing NETwork) and CSHNET (the Chinese Sun Hazemeter Network) were established to obtain data on aerosol optical characteristics (H. Che et al., 2009, 2015; Xin et al., 2007). High-frequency, ground-based measurements of aerosol optical properties made at these stations have improved our understanding of the sources, transport and diurnal variations of air pollutants, and they have provided insights into the aerosols' effects on climate.
Ground-based observations are also useful for the validation of satellite retrievals (Holben et al., 2017; Xie et al., 2011).

Most of the ground-based studies of the optical properties of aerosols in China have been conducted in urban regions that have been undergoing rapid economic development. Those sites typically have had high aerosol loadings and in many cases serious environmental problems (Cheng et al., 2015; Pan et al., 2010; Xia et al., 2013; L. C. Wang et al., 2015; H. Z. Che et al., 2015). Detailed information on aerosol optical depth (AOD), the types of aerosols and especially the size and absorption properties of ambient populations over a wide sampling of regions is needed to understand the effects of aerosols on the Earth's climate and the environment (Giles et al., 2011; H. Z. Che et al., 2009; Wang et al., 2010; Zhu et al., 2014). In particular, the aerosol direct radiative forcing is sensitive to the aerosol radiation absorptivity (Haywood and Shine, 1995). Therefore, it is important to understand the connections between the aerosol types and absorption properties because that information can be used for comparisons and validation of chemical transport models and satellites (J. Lee et al., 2010).

The Yangtze River Delta (YRD) region in eastern China has recently undergone rapid economic growth, and the loadings of aerosols in the region can be very high during heavy pollution episodes (Fu et al., 2008; Zhang et al., 2009). Studies of aerosol optical properties in eastern China have contributed to our understanding of local air quality and regional climate impacts (Duan and Mao, 2007; Pan et al., 2010; Ding et al., 2016). In the YRD, investigations of aerosol optical properties have been conducted in Nanjing, Hefei, Shanghai, Shouxian and Taihu (Zhuang et al., 2014; S. Li et al., 2015; Wang et al., 2015; He et al., 2012; K. H. Lee et al., 2010; Cheng et al., 2015; Xia et al., 2007). Those studies mostly involved sampling at single sites $\sim 100 \mathrm{~km}$ apart from one other without synchronous observations, and many have been of relatively short duration, and so there remains a need for more extensive ground-based measurements.

For the present study, sampling was conducted over a period of several years to better characterize the climatology of the aerosol microphysical and optical properties, including aerosol absorptivity, and to improve estimates of direct aerosol radiative forcing. For these studies, sun photometer measurements were made at $3 \mathrm{~min}$ intervals from 2011 to 2015 at seven CARSNET sites (one densely populated urban site, five urban center sites in smaller cities and one rural site) $\sim 10-40 \mathrm{~km}$ apart in the YRD. The dense network of ground-based sun-scanning and sky-scanning spectral radiometers improves the temporal and spatial coverage of the data, and that has enabled us to capture small-scale variations in the aerosols. The results not only contribute to our understanding of regional climate and local air quality impacts, but they also will be useful for validation of satellite data and improving the performance of models and remote sensing algorithms in the future. 
This paper is organized as follows: Sect. 2 describes the sites, the methods used for retrieving the aerosol optical properties and their uncertainties and the calculation of aerosol direct radiative forcing from the retrieved aerosol optical parameters. Section 3 presents the aerosol microphysical properties, optical properties and calculations of direct radiative forcing. The aerosol type classification is also presented based on the aerosol optical parameters. Then a brief discussion is made about the analysis of this study. Section 4 details the conclusions.

\section{Site descriptions, measurements and methods}

Figure 1 shows the locations of the seven CARSNET sites of the YRD, and detailed information on the sites is included in Table 1. Hangzhou is a densely populated urban site with heavy vehicular traffic, and it is affected by various types of anthropogenic emissions. LinAn, Fuyang, Jiande, Xiaoshan and Tonglu are urban center sites in smaller cities, and they are all affected to varying degrees by anthropogenic activities, especially pollutants from industries and agriculture. The rural site of ChunAn has a small population, and there are few industrial sources nearby, so the effects from local or regional pollution are relatively small.

Sun photometers (CE-318, Cimel Electronique, Paris, France) were installed at each of the seven sites and operated from 2011 to 2015 . These instruments were standardized and calibrated using CARSNET reference instruments $(\mathrm{H}$. Che et al., 2009), which in turn were periodically calibrated at Izaña, Tenerife, Spain, in conjunction with the AERONET program. The cloud-screened AODs (based on the work of Smirnov et al., 2000) at 340, 380, 440, 500, 670, 870, 1020 and $1640 \mathrm{~nm}$ with uncertainties less than 0.01 (Eck et al., 1999) were obtained using ASTPwin software (Cimel Electronique). The water vapor expressed as precipitable water in the column was derived from the $940 \mathrm{~nm}$ channel with uncertainties less than $10 \%$ (Eck et al., 1999). Daily averages and statistical analysis were calculated for days on which instantaneous AOD measurements were made more than 10 times (H. Che et al., 2015). The extinction Angström exponent values (EAE) were calculated from AOD values at 440 and $870 \mathrm{~nm}$.

Aerosol microphysical properties were retrieved from the almucantar sky irradiance measurements in conjunction with measured spectral AOD, following the methods of Dubovik and King (2000) and Dubovik et al. (2002, 2006). The dataset contained information on (1) volume size distributions in 22 size bins for particle radii $0.05-15 \mu \mathrm{m}$; (2) fine-mode and coarse-mode aerosol effective radii; and (3) aerosol optical properties - including the wavelength-dependent singlescattering albedo (SSA), the complex refractive index, the absorption AOD (AAOD), and the absorption Angström exponent (AAE). For the retrieval process, the surface albedo (SA) was interpolated/extrapolated to 440, 670, 870 and $1020 \mathrm{~nm}$ from the daily Moderate Resolution Imaging Spectroradiometer (MODIS) surface reflectance product of MCD43C3 (https://ladsweb.modaps.eosdis.nasa.gov/). Following the procedures of Dubovik et al. (2002, 2006), all particles smaller than $0.992 \mu \mathrm{m}$ were considered fine-mode particles, while those larger than $0.992 \mu \mathrm{m}$ were considered coarse-mode particles. And the effective radii for the total $\left(R_{\text {eff }}\right)$, fine-mode $\left(R_{\text {eff }}\right.$ fine $)$ and coarse-mode $\left(R_{\text {eff }_{\text {coarse }}}\right)$ aerosols are calculated as follows:

$$
R_{\mathrm{eff}}=\frac{\int_{r_{\min }}^{r_{\max }} r^{3} \frac{\mathrm{d} N(r)}{\mathrm{d} \ln r} \mathrm{~d} \ln r}{\int_{r_{\min }}^{r_{\max }} r^{2} \frac{\mathrm{d} N(r)}{\mathrm{d} \ln r} \mathrm{~d} \ln r},
$$

where $r_{\min }$ is $0.05,0.05$ and $0.992 \mu \mathrm{m}$ and $r_{\max }$ is $15,0.992$ and $15 \mu \mathrm{m}$ for the total, fine-mode and coarse-mode aerosols, respectively.

The inversion algorithm used for calculating the aerosol volume distribution $(\mathrm{d} V / \ln r)$ assumed a homogeneous distribution of nonspherical aerosol particles as in the work of Dubovik et al. (2006); this approach has been widely applied in studies of many different areas of the world. The SSA was retrieved using only $\mathrm{AOD}_{440 \mathrm{~nm}}>0.40$ measurements to avoid the large uncertainties inherent in low AOD retrievals (Dubovik et al., 2002, 2006). Real and imaginary parts of the refractive index at 440,675, 870 and $1020 \mathrm{~nm}$ were constrained to the ranges of 1.33-1.60 and 0.0005-0.50, respectively (Dubovik and King, 2000; H. Che et al., 2015). The complex refractive index is assumed to be independent of particle size. This assumption is valid for fine-dominated or coarse-dominated cases; however, it could cause some errors in SSA and particle size retrievals for mixed aerosol scenarios (Xu and Wang, 2015; Xu et al 2015). The AOD, AAOD and AAE are related to one another as shown in Eqs. (2) and (3):

$$
\begin{aligned}
& \operatorname{AAOD}(\lambda)=[1-\operatorname{SSA}(\lambda)] \times \operatorname{AOD}(\lambda) \\
& \operatorname{AAE}=-\mathrm{d} \ln [\operatorname{AAOD}(\lambda)] / \mathrm{d} \ln (\lambda) .
\end{aligned}
$$

The inversion algorithms mentioned above have been used for AERONET and CARSNET, and the accuracies of the volume size distribution were $15-25 \%$ for $0.1 \mu \mathrm{m} \leq r \leq 7.0 \mu \mathrm{m}$ and $25-100 \%$ for $r<0.1 \mu \mathrm{m}$ and $r>7 \mu \mathrm{m}$. The accuracies for both AOD and AAOD are $\sim 0.01$. The errors for the total, fine-mode and coarse-mode SSA are about $0.030,0.037$ and 0.085 , respectively. The imaginary and real parts of the complex refractive index for the AOD at $440 \mathrm{~nm}>0.40$ and a solar zenith angle $>50^{\circ}$ have errors of $\sim 0.0025-0.0042$ and 0.04, respectively (Dubovik et al., 2000; J. Li et al., 2015).

The direct aerosol radiative forcing (DARF) values in units of $\mathrm{W} \mathrm{m}^{-2}$ were calculated using the radiative transfer module in the AERONET inversion (García et al., 2008, 2012) under the assumption of cloud-free conditions. The DARF is defined as the difference in the shortwave radiative fluxes between the two energy levels including and excluding aerosol 


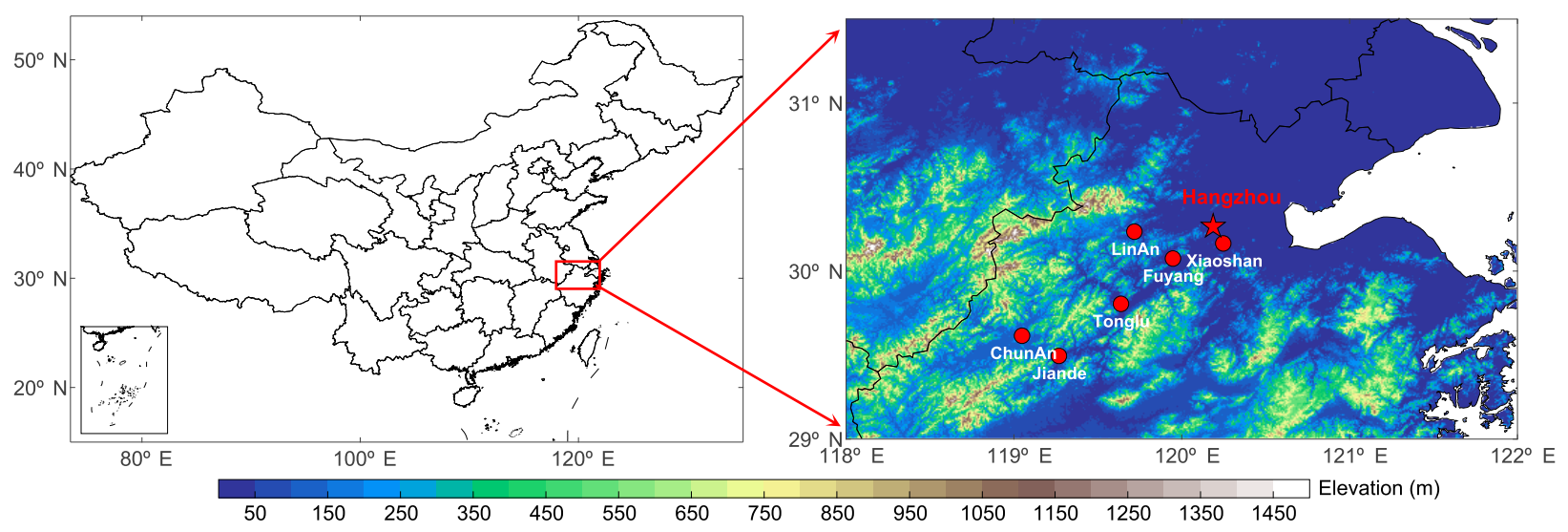

Figure 1. Locations and elevations of the seven CARSNET sites in the Yangtze River Delta.

effects at the Earth's surface (bottom of the atmosphere, BOA) and the top of the atmosphere (TOA) in Eqs. (4) and (5) as follows:

$$
\begin{gathered}
\text { DARF }_{\mathrm{TOA}}=F_{\mathrm{TOA}}^{\uparrow 0}-F_{\mathrm{TOA}}^{\uparrow} \\
\mathrm{DARF}_{\mathrm{BOA}}=F_{\mathrm{BOA}}^{\downarrow}-F_{\mathrm{BOA}}^{\downarrow 0},
\end{gathered}
$$

where $F$ and $F^{0}$ represent the broadband fluxes with and without aerosols at BOA and TOA, respectively. The arrows in these equations indicate the direction of the fluxes for the downward and upward cases. Defined this way, a negative value for $\Delta F$ indicates aerosol cooling effects, while positive values imply warming, both at the BOA and the TOA.

In the radiative transfer module used here, the flux calculations accounted for absorption and multiple scattering effects using the discrete ordinates (DISORT) approach (Stamnes et al., 1988; Nakajima and Tanaka, 1988). The solar broadband fluxes from 0.2 to $4.0 \mu \mathrm{m}$ were simulated by using information on aerosol properties (size distribution, spectral AOD, SSA and phase function) obtained from the ground-based measurements. The spectral refractive indices (both real and imaginary parts) were interpolated/extrapolated from the values retrieved at four distinct wavelengths $(440,670,870$, $1020 \mathrm{~nm}$ ) from the ground-based sun photometers. Likewise, the spectral dependence of surface reflectance was interpolated/extrapolated from surface albedo values used in the aerosol property retrieval process for the same wavelengths.

The integrated effects of atmospheric aerosol scattering and absorption, gaseous absorption and molecular scattering and underlying surface reflection effects were evaluated using the Global Atmospheric ModEl (GAME) code (Dubuisson et al., 1996; Roger et al., 2006). In the GAME code, gaseous absorption (mainly $\mathrm{H}_{2} \mathrm{O}, \mathrm{CO}_{2}$ and $\mathrm{O}_{3}$ ) is calculated from the correlated $k$ distribution (Lacis and Oinas, 1991). The instantaneous column water vapor content was retrieved by the absorption differential method from the $0.94 \mathrm{~mm}$ channel (Smirnov et al., 2004). The total ozone content was taken from monthly climatology values based on the Total
Ozone Mapping Spectrometer (TOMS) measurements. The GAME model accounts for spectral gaseous absorption; that is, ozone in the ultraviolet-visible spectral range $(0.20-0.35$ and $0.5-0.7 \mu \mathrm{m})$ and water vapor in the shortwave infrared spectrum $(0.8-3.0 \mu \mathrm{m})$.

The flux calculations were performed for a multi-layered atmosphere with the US standard 1976 atmosphere model for gaseous distributions and single fixed aerosol vertical distribution (exponential with an aerosol height of $1 \mathrm{~km}$ ) (García et al., 2008). As these authors have pointed out, solar fluxes calculated using the module described above show excellent agreement with ground-based measurements of solar radiation (slope of $0.98 \pm 0.00$ and bias of $-5.32 \pm 1.00 \mathrm{~W} \mathrm{~m}^{-2}$ ) with a correlation of $99 \%$. There is a small overestimation of $+9 \pm 12 \mathrm{~W} \mathrm{~m}^{-2}$ of the observed solar radiation at the surface in global terms, and this corresponds to a relative error of $+2.1 \pm 3.0 \%$. The differences range from $+14 \pm 10$ to $+6 \pm 13 \mathrm{~W} \mathrm{~m}^{-2}$ for urban/industrial and biomass burning aerosols, respectively. The errors are expected to be of the same magnitude at the TOA, since the same methodology and inputs are used at both levels (gaseous and aerosol distribution, radiative model, etc).

\section{Results and discussion}

\subsection{Aerosol microphysical properties: particle radius and volume size distributions}

Figure 2 shows the monthly aerosol size distribution $(\mathrm{d} V / \mathrm{d} \ln r)$ for all seven sites in the YRD. The annual mean values for the effective radii of the total particles $\left(R_{\text {eff }_{\mathrm{t}}}\right)$ were $\sim 0.30 \mu \mathrm{m}$, and the average annual volume was $\sim 0.18 \mu \mathrm{m}^{3} \mu \mathrm{m}^{-2}$ (Table 1). The fine-mode effective radii averaged $\sim 0.16 \mu \mathrm{m}$ in the YRD with a fractional volume of $0.10-0.11 \mu \mathrm{m}^{3} \mu \mathrm{m}^{-2}$, while the coarse-mode average effective radii were $\sim 2.2 \mu \mathrm{m}$ with a fractional volume $\sim 0.08 \mu \mathrm{m}^{3} \mu \mathrm{m}^{-2}$. These results show that there was a 

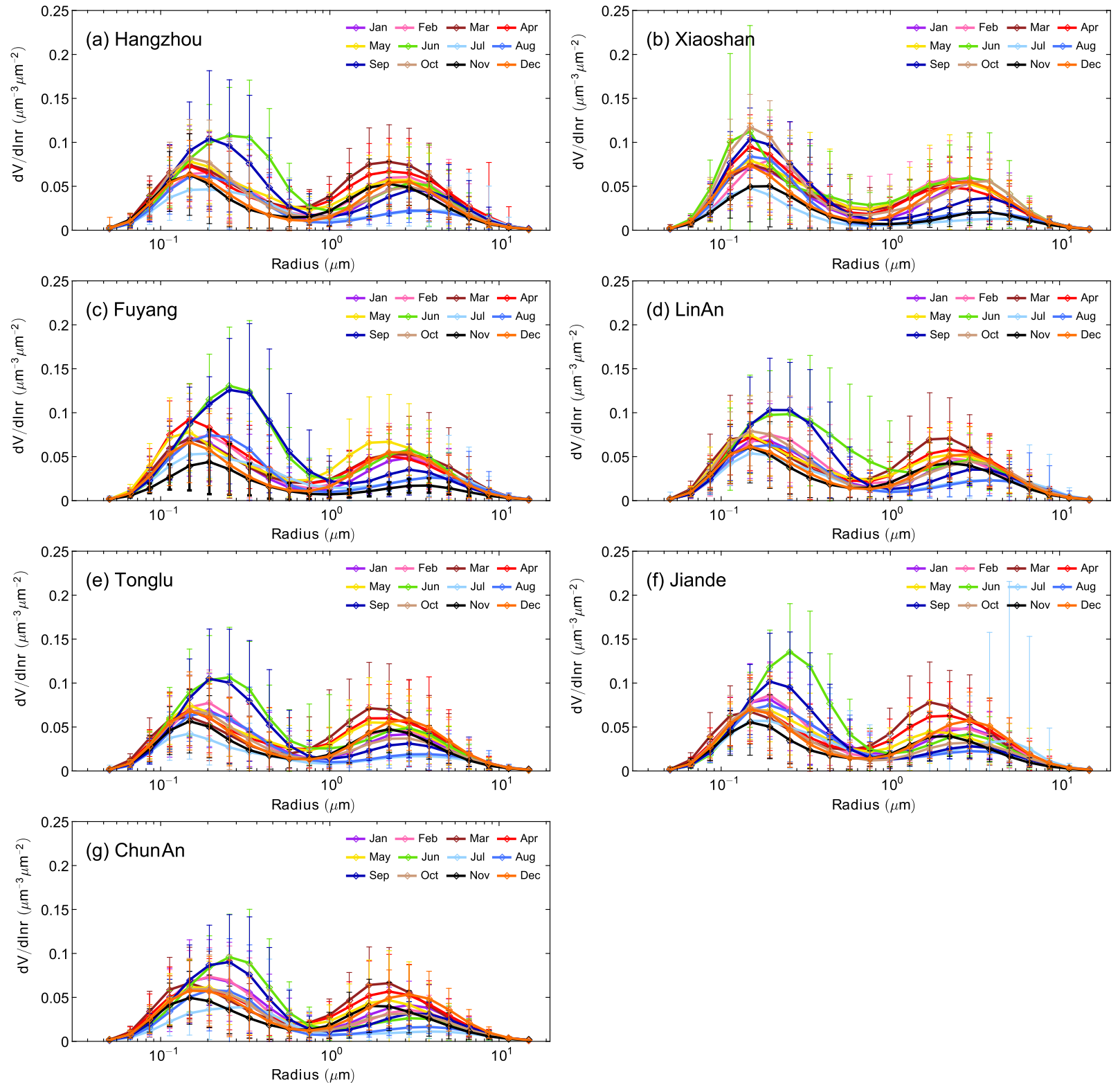

Figure 2. Temporal variations in the aerosol volume-size distributions at (a) Hangzhou, (b) Xiaoshan, (c) Fuyang, (d) LinAn, (e) Tonglu, (f) Jiande and (g) ChunAn.

larger contribution of fine-mode particles to the aerosol volume compared with the coarse-mode particles at all sites. The total and fine-mode aerosol volumes and effective radii showed small differences from the densely populated urban site (Hangzhou) to the urban center sites in smaller cities (Xiaoshan, Fuyang, LinAn, Tonglu, Jiande) or the rural site (ChunAn), and this reflects a generally homogeneous distribution of the aerosol in the YRD. The coarse-mode aerosol volumes also showed small differences among the sites, but the range of effective radii varied $2.16-2.30 \mu \mathrm{m}$.

Higher volumes and larger effective radii of the fine-mode particles were observed in June and September at most sites, and again there were relatively small differences among sites; the exception was Xiaoshan where the month-to-month differences in these variables were less pronounced (Fig. 2). The increases in submicron particles during the summer may have been caused in part by the hygroscopicity of the aerosols. In this regard, Saha and Morty (2004) reported that the volume of accumulation-mode particles increased faster than the coarse-mode particles under high relative humidity conditions. At our sites, the precipitation in June and September was greater than in the other months because of the Meiyu flood period and the typhoon and autumn rain period, respectively. Indeed, the major aerosol components, 
which include sulfate, nitrate, ammonium and organic compounds, can cause severe haze-fog events during high relative humidity conditions. Fine particles containing sulfate, nitrate and ammonium are hygroscopic, and their sizes are strongly affected by the relative humidity (Fu et al., 2008; Shen et al., 2015; S. Li et al., 2015; Huang et al., 2016). Additionally, broad fine-mode distributions may result from the occurrence of fog or low-altitude cloud dissipation events (Eck et al., 2012; Li et al., 2010, 2014). Eck et al. (2012) also pointed out that a large range of fine-mode aerosol sizes may result from cloud processing, and that also could contribute to a shoulder of larger size particles in the accumulation mode, especially in regions where sulfate and other water-soluble aerosols exist. Another interesting observation is that the fine-mode aerosol volume in July was relatively low at all sites and is coincident with lower relative humidity in July $(\sim 60 \%)$ compared with that in June $(\sim 80 \%)$ in the YRD. Therefore, the hygroscopic effects on fine particles in July evidently are not as obvious as in June or September.

High volumes for coarse-mode aerosol occurred in March to May at all sites, and this suggests that more large particles occurred in spring than in the other seasons. The most likely explanation for this is the presence of mineral dust in the YRD region at that time of year. High $\mathrm{PM}_{10}$ mass concentrations of Hangzhou during 2012-2015 showed $78.5 \pm 15.4,84.7 \pm 11.3$ and $83.6 \pm 15.5 \mu \mathrm{g} \mathrm{m}^{-3}$ in March, April and May, respectively (see the Supplement), which is consistent with the results of relative large coarse-mode aerosol volumes in this study. As Cao et al. (2009) pointed out, fugitive dust can account for about one-third of $\mathrm{PM}_{10}$ mass concentration in Hangzhou, and that mainly came from resuspended road dust and construction soil. The long-range transportation of dust in spring from northern/northwestern China could also contribute to the high coarse-mode aerosol volume. For instance, Fu et al. (2014) and Sun et al. (2017) found that dust particles could be transported long distances, and the impacts were apparent in the YRD. Low volumes and large bandwidths of coarse-mode aerosol were found in July and August at all sites, and that may have been due to the wet removal of coarse particles by the heavy precipitation in June. In July and August, strong convection associated with subtropical anticyclone can disperse the aerosol. These results also are consistent with previous reports showing minimum $\mathrm{PM}_{10}$ concentrations in summer of the YRD region (Cao et al., 2009). It was found the $\mathrm{PM}_{10}$ mass concentrations of Hangzhou during 2012-2015 were relatively low, with values of $53.2 \pm 6.8$ and $56.7 \pm 4.4 \mu \mathrm{g} \mathrm{m}^{-3}$ in July and August, respectively (see the Supplement). Sun et al. (2013) found that aerosol size distributions can broaden under unstable weather conditions, and in July and August, the weather in the YRD can become unstable due to the high temperatures, and this could be another factor that contributed to the large bandwidth of both fine-mode and coarse-mode particles in our study. However, these possible connections should be re-visited in the future.

\subsection{Aerosol optical properties: AOD and EAE}

The arithmetic mean annual values for $\mathrm{AOD}_{440 \mathrm{~nm}}$ at the six urban sites (Hangzhou, Xiaoshan, Fuyang, LinAn, Tonglu, Jiande) were $0.71-0.76$ and 0.68 at the rural site of ChunAn (Table 1). The difference in AOD between urban and rural sites was $<10 \%$, and this indicates that there were widespread anthropogenic impacts on the aerosol populations in the YRD and that the high particle concentrations extend beyond the local to the regional scale. Nonetheless, the $\mathrm{AOD}_{440 \mathrm{~nm}}$ generally decreased from the east coast to inland areas towards the west (0.76 at Hangzhou, 0.73 at LinAn, 0.71 at Jiande and 0.68 at ChunAn), and this can be explained by stronger anthropogenic impacts in the more urbanized east. The high $\mathrm{AOD}_{440 \mathrm{~nm}}$ at Hangzhou was likely the result of the greater industrial activity and higher population density in the eastern part of that metropolitan region; both of those factors could lead to larger aerosol emissions compared with the less populated urban and rural sites. The coarse-mode AOD values were just $\sim 0.06$ to 0.08 , and the ratio of the fine-mode $\mathrm{AOD}_{440 \mathrm{~nm}}$ to the total $\mathrm{AOD}_{440 \mathrm{~nm}}$ varies from 0.89 to 0.91 at the sites, and therefore, fine-mode particles clearly were the main contributors to light extinction in the region. The lower coarse-mode fraction of total aerosol extinction $(\sim 10 \%)$ indicated that the contribution of coarse particles to aerosol loading in the YRD region is not as obvious as in other northern/northeastern China region (Zhang et al., 2012).

Unlike one peak $\mathrm{AOD}_{440 \mathrm{~nm}}$ distribution found in JuneAugust over northern and northeastern China $(\mathrm{H}$. Che et al., 2015), the monthly averaged AODs at $440 \mathrm{~nm}$ at all seven sites showed two peaks, one in June and the other in September (Fig. 3), with mean values of $\sim 1.26 \pm 0.50$ (FMF $\sim 0.93$ ) and $\sim 1.03 \pm 0.57$ (FMF $\sim 0.95$ ), respectively. The FMF is defined as the fine-mode particle $\mathrm{AOD}_{440 \mathrm{~nm}}$ fraction $\left(\mathrm{AOD}_{\text {fine }}(440 \mathrm{~nm}) / \mathrm{AOD}_{440 \mathrm{~nm}}\right)$. Low $\mathrm{AOD}_{440 \mathrm{~nm}}$ values of $\sim 0.40-0.60$ were found in July and August throughout the region, and these low values are consistent with the discussion above concerning aerosol microphysical characteristics. That is, hygroscopic effects and/or cloud processing of fine-mode aerosol particles caused greater extinction in June and September compared with July and August. Zhang et al. (2015) reported that the hygroscopic particles under high relative humidity conditions could cause strong aerosol light scattering in the Yangtze River Delta. Other meteorological factors also may have played a role in the variations in $\mathrm{AOD}_{440 \mathrm{~nm}}$ during summer because in July and August, subtropical high-pressure systems prevail, and the planetary boundary layer (PBLH) at Hangzhou is deep, $\sim 1.5-$ $2.0 \mathrm{~km}$ (Sun et al., 2017). The large PBLH associated with subtropical anticyclones favors aerosol dispersion, and this can help explain the relatively low aerosol extinction observed in July and August. In January and February, high $\mathrm{AOD}_{440 \mathrm{~nm}}$ values (0.71-0.89) were observed at all sites, and this can be attributed to emissions from residential heat- 
Table 1. Geographical location and annual arithmetic mean optical parameters for aerosols from seven sites in the Yangtze River Delta.

\begin{tabular}{|c|c|c|c|c|c|c|c|}
\hline & Hangzhou & Xiaoshan & Fuyang & LinAn & Tonglu & Jiande & ChunAn \\
\hline Site type & Urban & Suburban & Suburban & Suburban & Suburban & Suburban & Rural \\
\hline Longitude $\left({ }^{\circ} \mathrm{E}\right)$ & 120.19 & 120.25 & 119.95 & 119.72 & 119.64 & 119.27 & 119.05 \\
\hline Latitude $\left({ }^{\circ} \mathrm{N}\right)$ & 30.26 & 30.16 & 30.07 & 30.23 & 29.80 & 29.49 & 29.61 \\
\hline Altitude (m) & 41.9 & 14.0 & 17.0 & 139 & 46.1 & 88.9 & 171.4 \\
\hline$N_{\text {day }}{ }^{\mathrm{a}}$ & 485 & 180 & 217 & 562 & 498 & 480 & 439 \\
\hline$N_{\text {inst. }}$ b & 2052 & 752 & 906 & 2410 & 2255 & 1952 & 1731 \\
\hline $\mathrm{AOD}_{440 \mathrm{~nm}^{\mathrm{c}}}$ & $0.76 \pm 0.42$ & $0.76 \pm 0.43$ & $0.76 \pm 0.45$ & $0.73 \pm 0.44$ & $0.71 \pm 0.41$ & $0.73 \pm 0.40$ & $0.68 \pm 0.38$ \\
\hline $\mathrm{AOD}_{\text {fine }(440 \mathrm{~nm})^{\mathrm{c}}}$ & $0.68 \pm 0.42$ & $0.69 \pm 0.41$ & $0.69 \pm 0.44$ & $0.66 \pm 0.43$ & $0.64 \pm 0.41$ & $0.66 \pm 0.40$ & $0.61 \pm 0.38$ \\
\hline AOD $\left._{\text {coarse }(440 \mathrm{~nm})}\right)^{\mathrm{c}}$ & $0.08 \pm 0.06$ & $0.07 \pm 0.06$ & $0.07 \pm 0.06$ & $0.07 \pm 0.07$ & $0.07 \pm 0.06$ & $0.07 \pm 0.07$ & $0.06 \pm 0.05$ \\
\hline $\mathrm{EAE}_{440-870 \mathrm{~nm}^{\mathrm{d}}}$ & $1.29 \pm 0.26$ & $1.37 \pm 0.24$ & $1.32 \pm 0.24$ & $1.29 \pm 0.27$ & $1.30 \pm 0.26$ & $1.32 \pm 0.28$ & $1.22 \pm 0.25$ \\
\hline $\mathrm{SSA}_{440 \mathrm{~nm}^{\mathrm{c}}}$ & $0.91 \pm 0.06$ & $0.93 \pm 0.04$ & $0.94 \pm 0.04$ & $0.93 \pm 0.05$ & $0.92 \pm 0.04$ & $0.92 \pm 0.05$ & $0.94 \pm 0.03$ \\
\hline $\mathrm{SSA}_{670 \mathrm{~nm}}{ }^{\mathrm{e}}$ & $0.92 \pm 0.06$ & $0.91 \pm 0.06$ & $0.93 \pm 0.06$ & $0.92 \pm 0.05$ & $0.93 \pm 0.05$ & $0.92 \pm 0.07$ & $0.94 \pm 0.03$ \\
\hline $\mathrm{SSA}_{870 \mathrm{~nm}^{\mathrm{f}}}$ & $0.90 \pm 0.07$ & $0.90 \pm 0.07$ & $0.91 \pm 0.08$ & $0.91 \pm 0.06$ & $0.91 \pm 0.06$ & $0.90 \pm 0.08$ & $0.93 \pm 0.04$ \\
\hline $\mathrm{SSA}_{1020 \mathrm{~nm}^{\mathrm{g}}}$ & $0.89 \pm 0.08$ & $0.89 \pm 0.08$ & $0.89 \pm 0.09$ & $0.90 \pm 0.07$ & $0.90 \pm 0.07$ & $0.90 \pm 0.09$ & $0.92 \pm 0.05$ \\
\hline $\mathrm{AAOD}_{440 \mathrm{~nm}^{\mathrm{c}}}$ & $0.06 \pm 0.05$ & $0.05 \pm 0.04$ & $0.04 \pm 0.04$ & $0.05 \pm 0.04$ & $0.05 \pm 0.04$ & $0.06 \pm 0.04$ & $0.04 \pm 0.03$ \\
\hline $\mathrm{AAE}_{440-870 \mathrm{~nm}}{ }^{\mathrm{d}}$ & $1.13 \pm 0.46$ & $0.88 \pm 0.42$ & $0.85 \pm 0.43$ & $0.98 \pm 0.35$ & $1.11 \pm 0.49$ & $1.16 \pm 0.44$ & $0.93 \pm 0.31$ \\
\hline$R_{\mathrm{eff}_{\mathrm{t}}}(\mu \mathrm{m})^{\mathrm{c}}$ & $0.30 \pm 0.10$ & $0.29 \pm 0.09$ & $0.30 \pm 0.09$ & $0.29 \pm 0.10$ & $0.29 \pm 0.10$ & $0.29 \pm 0.09$ & $0.30 \pm 0.10$ \\
\hline$R_{\text {eff }_{\text {fine }}}(\mu \mathrm{m})^{\mathrm{c}}$ & $0.16 \pm 0.04$ & $0.16 \pm 0.03$ & $0.17 \pm 0.04$ & $0.16 \pm 0.04$ & $0.16 \pm 0.04$ & $0.17 \pm 0.04$ & $0.17 \pm 0.04$ \\
\hline$R_{\text {eff }}$ coarse $(\mu \mathrm{m})^{\mathrm{c}}$ & $2.21 \pm 0.40$ & $2.26 \pm 0.35$ & $2.30 \pm 0.39$ & $2.24 \pm 0.44$ & $2.19 \pm 0.41$ & $2.16 \pm 0.39$ & $2.27 \pm 0.42$ \\
\hline Volume $\left(\mu \mathrm{m}^{3} \mu \mathrm{m}^{-2}\right)^{\mathrm{c}}$ & $0.19 \pm 0.09$ & $0.19 \pm 0.09$ & $0.19 \pm 0.09$ & $0.18 \pm 0.09$ & $0.17 \pm 0.09$ & $0.18 \pm 0.09$ & $0.17 \pm 0.07$ \\
\hline Volume $_{\text {fine }}\left(\mu \mathrm{m}^{3} \mu \mathrm{m}^{-2}\right)^{\mathrm{c}}$ & $0.10 \pm 0.06$ & $0.11 \pm 0.06$ & $0.11 \pm 0.07$ & $0.10 \pm 0.06$ & $0.10 \pm 0.06$ & $0.10 \pm 0.06$ & $0.10 \pm 0.06$ \\
\hline Volume $_{\text {coarse }}\left(\mu \mathrm{m}^{3} \mu \mathrm{m}^{-2}\right)^{\mathrm{c}}$ & $0.09 \pm 0.06$ & $0.08 \pm 0.05$ & $0.08 \pm 0.06$ & $0.08 \pm 0.05$ & $0.08 \pm 0.06$ & $0.08 \pm 0.07$ & $0.07 \pm 0.05$ \\
\hline DARF-BOA $\left(\mathrm{W} \mathrm{m}^{-2}\right)^{\mathrm{c}}$ & $-93 \pm 44$ & $-84 \pm 41$ & $-80 \pm 40$ & $-81 \pm 39$ & $-79 \pm 39$ & $-82 \pm 40$ & $-74 \pm 34$ \\
\hline DARF-TOA $\left(\mathrm{W} \mathrm{m}^{2}\right)^{\mathrm{c}}$ & $-35 \pm 20$ & $-36 \pm 21$ & $-37 \pm 21$ & $-36 \pm 21$ & $-35 \pm 20$ & $-35 \pm 21$ & $-40 \pm 19$ \\
\hline
\end{tabular}

${ }^{a}$ Number of available observation days. ${ }^{b}$ Number of instantaneous observations. ${ }^{c}$ Optical parameters at a wavelength of $440 \mathrm{~nm} .{ }^{\mathrm{d}}$ Angström exponents between 440 and $870 \mathrm{~nm} .{ }^{\mathrm{e}}$ Optical parameters at a wavelength of $670 \mathrm{~nm}$. ${ }^{\mathrm{f}}$ Optical parameters at a wavelength of $870 \mathrm{~nm} .{ }^{\mathrm{g}}$ Optical parameters at a wavelength of $1020 \mathrm{~nm}$.

ing and the stability of the atmosphere, which can cause the near-surface accumulation of aerosol particles. The high $\mathrm{AOD}_{440 \mathrm{~nm}}$ values in winter also are consistent with studies by Cao et al. (2009), who reported that the $\mathrm{PM}_{10}$ mass concentrations at Hangzhou were highest in winter. According to the $\mathrm{PM}_{10}$ mass concentration measurements during 20122015 at Hangzhou, it was found that the $\mathrm{PM}_{10}$ mass concentrations were about $82.2 \pm 9.5,59.1 \pm 6.0,82.8 \pm 13.9$ and $92.3 \pm 14.3 \mu \mathrm{g} \mathrm{m}^{-3}$ in spring, summer, autumn and winter, respectively (see the Supplement).

The extinction Angström exponent (EAE $=$ $-\mathrm{d} \ln [\operatorname{EAOD}(\lambda)] / \mathrm{d} \ln (\lambda))$ can be regarded as an indicator of aerosol size; that is, $\mathrm{EAE}_{440-870 \mathrm{~nm}}>1.00$ typically indicates that the aerosol particles are small. The mean extinction Angström exponent at all seven CARSNET sites was higher than 1.20 throughout the year (Table 1), which means that small particles were predominant. This finding is consistent with the reported dominance of small particles from anthropogenic emissions and agricultural activity in the region (Tan et al., 2009).

\subsection{Aerosol optical properties: single-scattering albedo}

The SSAs at $440 \mathrm{~nm}$ at our seven sites in the YRD region varied from 0.91 to 0.94 (Table 1), and box plots of the monthly SSAs at wavelengths of 440, 670, 870 and $1020 \mathrm{~nm}$ are shown in Fig. 4. Eck et al. (2005) reported that the SSAs at $440 \mathrm{~nm}$ from AERONET retrievals were confined to a relatively narrow range of values globally from $\sim 0.82$ to 0.98 . Therefore, the SSA values in this study may be explained by moderately to strongly absorbing aerosols from industrial emissions and other anthropogenic sources. The $\mathrm{SSA}_{440 \mathrm{~nm}}$ at Hangzhou site was $0.91 \pm 0.06$, which is lower than that at the rural ChunAn site $(0.94 \pm 0.03)$. As Dubovik et al. (2000, $2002,2006)$ reported, the SSA depends on two factors particle size and composition. From Table 1, one can see that the differences in effective radii for total, fine-mode and coarse-mode particles between Hangzhou and ChunAn are quite small, and therefore, the differences in SSAs between the two sites can best be explained by differences in composition. Furthermore, the differences in SSAs between these sites indicate that there was a higher percentage of absorbing aerosols at urban sites than the rural one.

The SSAs for seven sites showed significant month-tomonth variations. The increased scattering (light-absorbing) effects seen in June can be attributed to hygroscopic growth, which can modify aerosol properties greatly (Xia et al., 2007). The presence of light-absorbing dust aerosols in spring and of absorbing aerosols from biomass burning in 

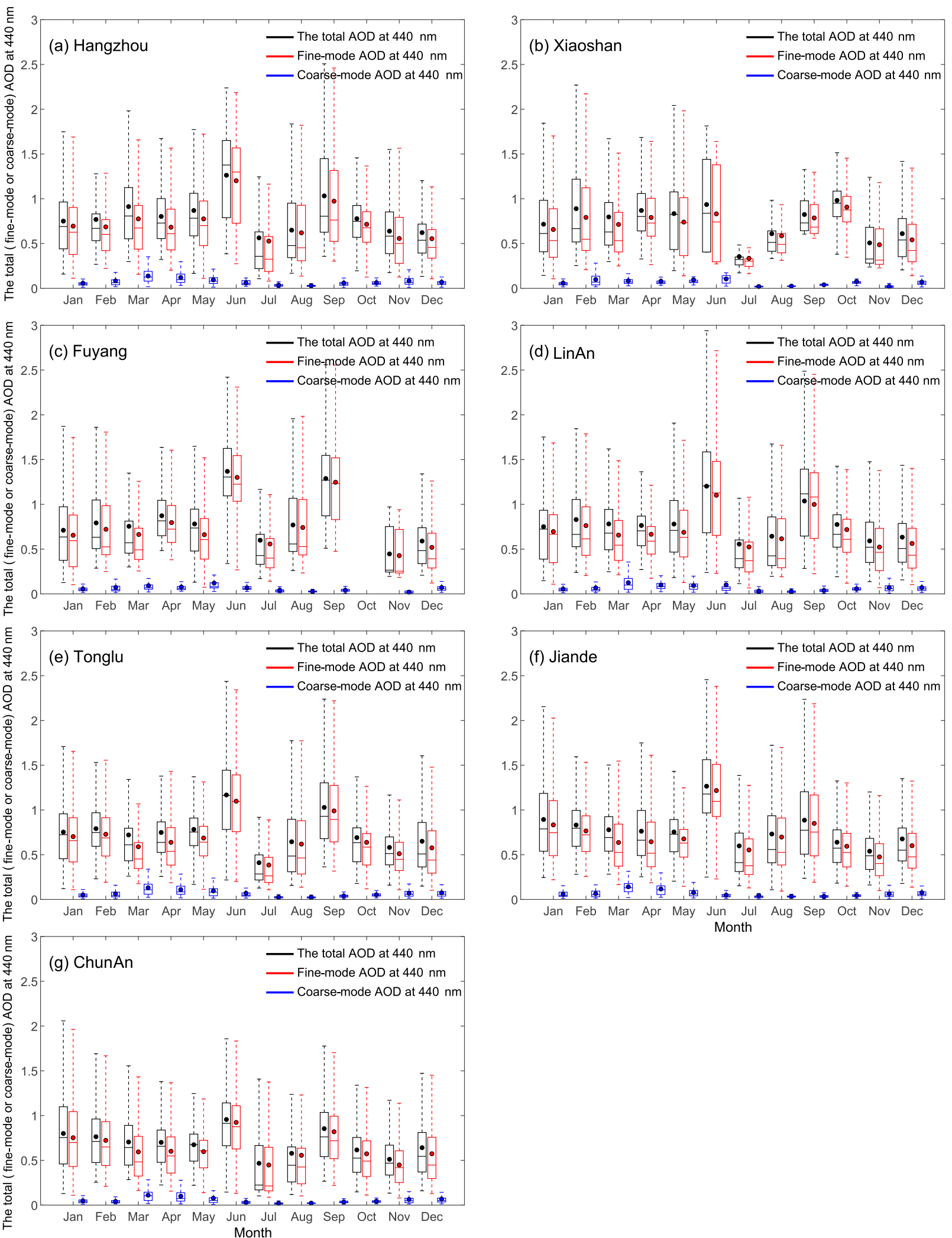

Figure 3. Variations in the total, fine-mode and coarse-mode $\mathrm{AOD}_{440 \mathrm{~nm}}$ at (a) Hangzhou, (b) Xiaoshan, (c) Fuyang, (d) LinAn, (e) Tonglu, (f) Jiande and (g) ChunAn. The boxes represent the 25th to 75 th percentiles of the distributions while the dots and solid lines within each box represent the means and medians, respectively. 

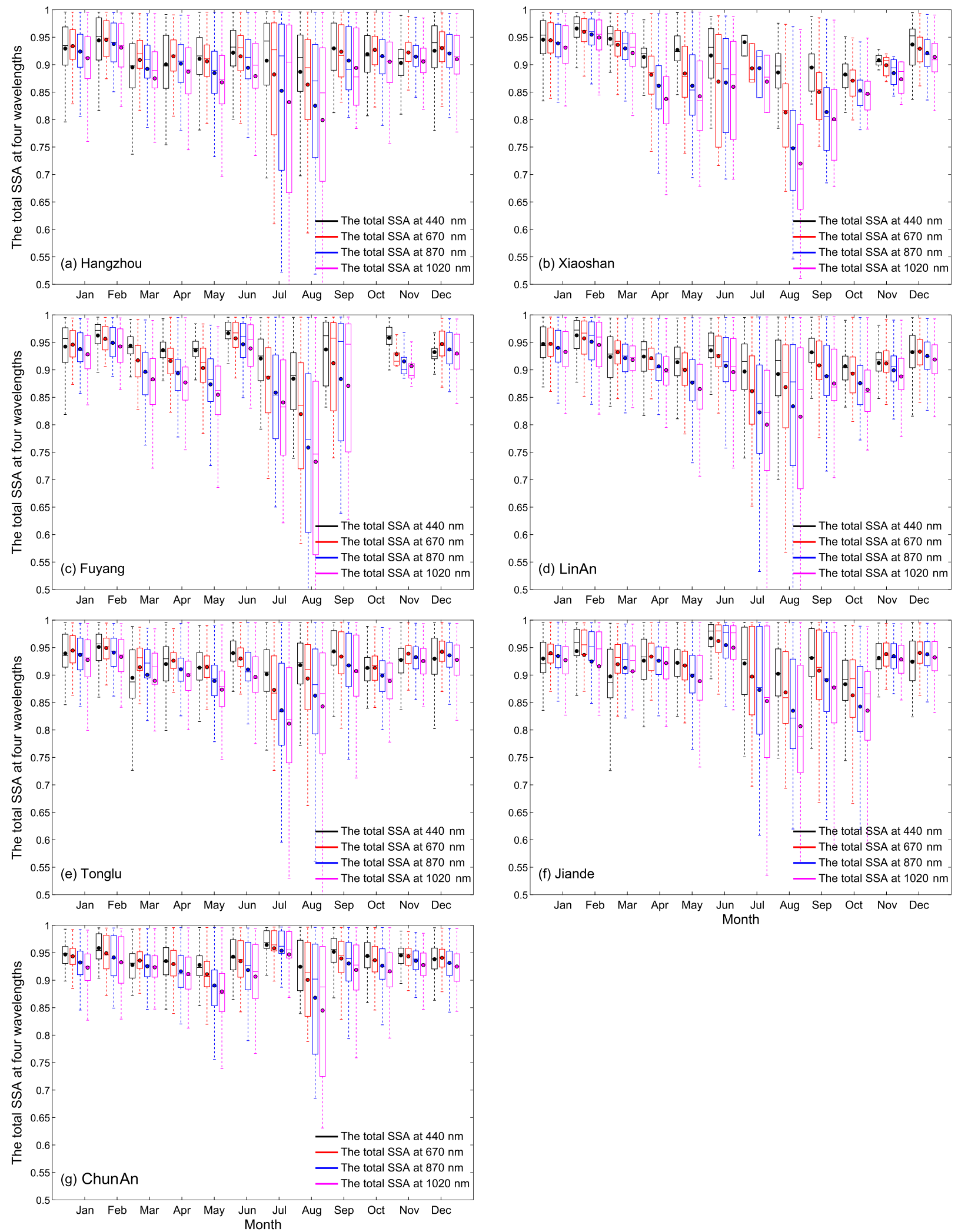

Figure 4. Variations in the single-scattering albedo at 440, 670, 870 and $1020 \mathrm{~nm}$ at (a) Hangzhou, (b) Xiaoshan, (c) Fuyang, (d) LinAn, (e) Tonglu, (f) Jiande and (g) ChunAn. See Fig. 3 for an explanation of the symbols. 
August was probably responsible for the differences in SSA values observed between those months because of the distinct differences in the intensive optical properties of dust and biomass burning products (Yang et al., 2009). At Hangzhou, the monthly average SSA values at $440 \mathrm{~nm}$ were relatively high in February $(\sim 0.94 \pm 0.05)$ and June $(\sim 0.92 \pm 0.06)$ and more moderate in March $(\sim 0.90 \pm 0.06)$ and August $(\sim 0.89 \pm 0.09)$. In comparison, the differences in monthly SSA values at the rural ChunAn site were smaller, only varying from 0.92 to 0.95 . We conclude from the temporal patterns of the SSAs that the types of aerosols at the urban/suburban sites were more variable than at the rural sites.

The SSA wavelength dependence is a function of the specific absorption/scattering properties of different aerosol types (Sokolik and Toon, 1999; Eck et al., 2010). The SSA for mineral dust particles typically shows a strong wavelength dependence from 440 to $1020 \mathrm{~nm}$, with a low value at $440 \mathrm{~nm}$ due to iron oxide absorption (Cheng et al., 2006; Dubovik et al., 2002). In spring, especially in March, the SSA was obviously lower at shorter wavelengths than at the longer ones, and this implies absorption by dust particles. This conclusion is consistent with the discussion above concerning the impact of dust on aerosol size distributions. In addition, there was a significant decrease in SSA at shorter wavelengths in July and August at most sites, and this supports the presence of aerosol particles with strong absorption, especially at infrared wavelengths. The decreases in those months can be explained by strongly absorbing aerosols from biomass burning or possibly industrial emissions. As Ding et al. (2013a, b) and Wang and Zhang (2008) have reported, plumes from agricultural burning typically contain lightabsorbing carbonaceous aerosols, and these pollutants can seriously impair air quality. Indeed, aerosols from biomass burning were more than likely responsible for the low in SSAs found in our study during July and August.

\subsection{Aerosol optical properties: AAOD and AAE}

The AAODs at $440 \mathrm{~nm}$ at the seven sites were similar $\sim 0.04-0.06$ (Fig. 5a and Table 1), and therefore, absorbing aerosols were apparently widely distributed throughout the YRD. There were large uncertainties in the $\mathrm{AAOD}_{440 \mathrm{~nm}}$, however; in fact, the standard deviations (0.03 to 0.05$)$ were comparable to the means, and this reflects the large temporal variability in absorbing aerosol particle loadings. The average $\mathrm{AAOD}_{440 \mathrm{~nm}}$ at Hangzhou was about 0.02 higher than that at ChunAn, and this shows that the relative proportion of absorbing particles at the urban area was larger than at the rural site, presumably due to greater anthropogenic emissions. From Fig. 5, one can see that the monthly AAOD $440 \mathrm{~nm}$ at the urban sites from March to November usually exceeded 0.05, which implies there were more absorbing species in spring and autumn compared with winter (December to February) when the $\mathrm{AAOD}_{440 \mathrm{~nm}}$ tended to be lower, $<0.05$. This result suggests that the relative abundances of light-absorbing par- ticles were lower in winter compared with other seasons, and this is different from many regions in northern China where the AAODs are highest in winter due to the emission of absorbing particles from residential heating and other sources (Zhao et al., 2015). At the ChunAn site, the variations in AAODs were smoother than the more heavily impacted urban sites, and the monthly mean AAODs at ChunAn were $<0.05$ throughout the year.

The AAE can be viewed as an indicator of the type of dominant absorbing aerosol particles, which include black carbon, organic matter and mineral dust (Giles et al., 2012). Generally, an $\mathrm{AAE}<1$ indicates mixing, coating and coagulation of black carbon with organic and inorganic materials; an AAE close to 1 indicates absorbing black carbon aerosols from the fossil fuel burning; and an AAE $>1.10$ indicates absorbing aerosols mainly from biomass burning or mineral dust (Russell et al., 2010; Bergstrom et al., 2007; Lack and Cappa, 2010). The annual mean AAEs at Hangzhou, Xiaoshan, Fuyang, LinAn, Tonglu, Jiande and ChunAn were $1.13 \pm 0.46,0.88 \pm 0.42,0.85 \pm 0.43$, $0.98 \pm 0.35,1.11 \pm 0.49,1.16 \pm 0.44$ and $0.93 \pm 0.31$, respectively (Table 1), and for discussion purposes, the seven sites were grouped into three categories based on their average AAEs. The mean AAE values at Xiaoshan and Fuyang were $<1.00$, which suggests that coated black carbon particles dominated at these two sites. However, this also could be due to measurement uncertainties due to smaller numbers of samples from those sites or to slightly larger values of the imaginary part of the refractive index at longer wavelengths for certain particles (Bergstrom et al., 2007). There would need to be more observations to confirm the low AAEs at these two sites.

The AAE values $\sim 1.00$ at LinAn and ChunAn indicate that the absorbing aerosol population was mainly composed of black carbon from fossil fuel burning. LinAn has a more developed economy compared with Tonglu and Jiande, and in comparison, LinAn has many more motor vehicles and is more heavily impacted by industrial emissions and fossil fuel combustion. In contrast, the ChunAn site is located in the Qiandao Lake National Water Resources Protection Zone where biomass burning and industrial activities are banned. Thus, emissions from motor vehicles are probably the main source of absorbing carbon aerosols at ChunAn. Finally, the AAE values at Hangzhou, Tonglu and Jiande were $>1.10$, indicating a predominance of light-absorbing aerosols from either biomass burning or mineral dust. Hangzhou has a population of $\sim 10$ million and more than one million vehicles, and the city can be impacted by fugitive dust and biomass burning emissions (Cao et al., 2009). Tonglu and Jiande have small economies compared with Hangzhou, but there is more agricultural production near these two sites, and they can be impacted by biomass burning. These inter-site differences in the AAEs reflect a degree of spatial heterogeneity in the distributions of absorbing aerosols even though the AODs were 

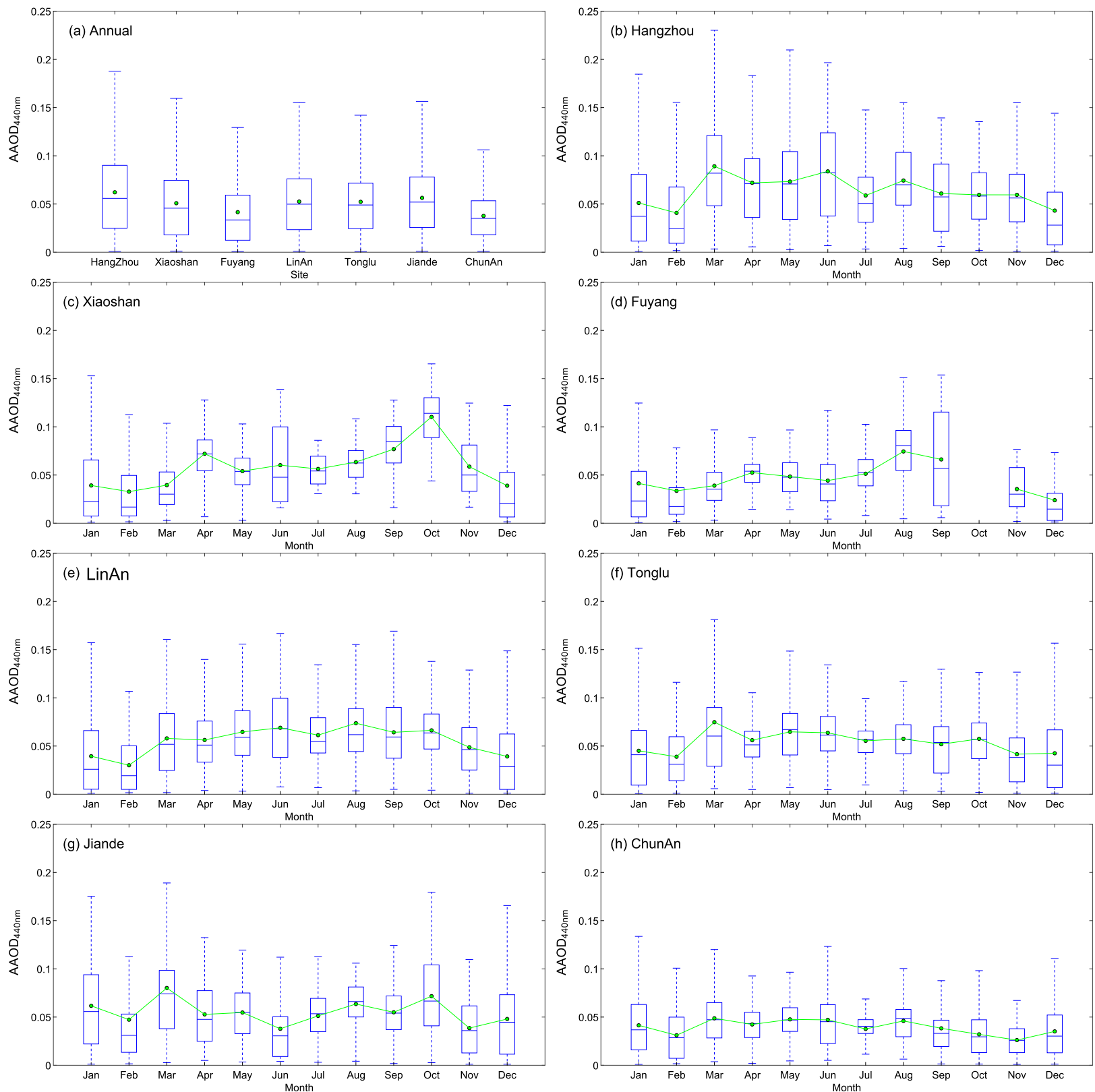

Figure 5. (a) Annual average absorption aerosol optical depths at $440 \mathrm{~nm}\left(\mathrm{AAOD}_{440 \mathrm{~nm}}\right)$ at the CARSNET sites and month-to-month variations in $\mathrm{AAOD}_{440 \mathrm{~nm}}$ at (b) Hangzhou, (c) Xiaoshan, (d) Fuyang, (e) LinAn, (f) Tonglu, (g) Jiande and (h) ChunAn. See Fig. 3 for an explanation of the symbols.

relatively similar, and these differences likely result from the many types of emission sources that can impact the sites.

\subsection{Direct aerosol radiative forcing at the Earth's surface and TOA}

In this study, only clear-sky direct aerosol radiative forcings could be investigated because the aerosol microphysical and optical parameters were derived from ground-based retrievals under cloud-free conditions. For the direct aerosol radiative forcing calculations, the solar fluxes are only evaluated for solar zenith angles (SZA) between 50 and $80^{\circ}$, which is where the solar geometry conditions are the most appropriate for retrieving the aerosol properties (Dubovik et al., 2000, 2002).

The annual direct DARF-BOA values under clear conditions for Hangzhou, Xiaoshan, Fuyang, LinAn, Tonglu, Jiande and ChunAn were $-93 \pm 44,-84 \pm 40,-80 \pm 40$, $-81 \pm 39,-79 \pm 39,-82 \pm 40$ and $-74 \pm 34 \mathrm{~W} \mathrm{~m}^{-2}$, respectively (Fig. 6a). The DARF-BOA at Hangzhou was 
$\sim-20 \mathrm{~W} \mathrm{~m}^{-2}$ lower than that at the rural ChunAn site. The DARFs at the Earth's surface and TOA are governed by the aerosol microphysical and optical properties, primarily particle size distributions, AODs and SSAs. The large number of negative DARF-BOA values at Hangzhou can be attributed to the high aerosol extinction $\left(\mathrm{AOD}_{440 \mathrm{~nm}} \sim 0.76\right)$ and small absorption (SSA at $440 \mathrm{~nm} \sim 0.91$ ). These calculations indicate that effects of those particles on radiative fluxes can cause significant surface cooling at that urban site. In comparison, at the rural ChunAn site, less negative DARF-BOA values result from lower aerosol extinction $\left(\mathrm{AOD}_{440 \mathrm{~nm}} \sim 0.68\right)$ and higher scattering $\left(\mathrm{SSA}_{440 \mathrm{~nm}} \sim 0.94\right)$.

The monthly DARF-BOA at the seven sites was most strongly negative in June, followed by March and September. The strong cooling effect at the surface in June was due to the high aerosol extinction (in Sect. 3.2) and in particular the high volumes of fine-mode particles as shown in Fig. 2. Weakly absorbing particles with $\mathrm{SSA}_{440 \mathrm{~nm}} \sim 0.90$ 0.95 (Fig. 6) also would reduce the flux of solar radiation to the surface. A large surface cooling effect also was found in March and April. Although the AOD in spring was lower than in winter, there were more strongly absorbing aerosols with relatively smaller SSAs at shorter wavelengths then, and this can be attributed to the presence of mineral aerosol particles. These coarse-mode particles with high volumes and large radii are common in spring (see Sect. 3.1), and they can absorb and scatter solar radiation, and in doing so cool the surface. Surface cooling in September can be explained by high aerosol extinction that resulted from the high volumes of weakly absorbing fine-mode particles $\left(\mathrm{SSA}_{440 \mathrm{~nm}} \sim 0.90\right.$ 0.95). These results indicate that the attenuation of the solar radiation by the aerosols leads to significant surface cooling over the YRD.

The DARF-TOA annual mean values under clear conditions were $\sim-40 \mathrm{~W} \mathrm{~m}^{-2}$ at all sites (Fig. 7a), and these negative DARF-TOA values indicate that the aerosols caused cooling of the whole earth-atmosphere system in the YRD. This is different from the case in northern/northeastern China where the instantaneous DARF-TOA value can be positive in winter due to the high surface reflectance of short wavelength radiation combined with atmospheric heating caused by absorbing aerosols (Zhao et al., 2015; Che et al., 2014).

The monthly DARF-TOA means under clear conditions varied smoothly during two periods: (1) from January to May and (2) from October to December (Fig. 7). The DARF-TOA values were found to be approximately $-40 \mathrm{~W} \mathrm{~m}^{-2}$ at all sites in the above two periods. However, the monthly DARFTOA means in June and September exceeded $-40 \mathrm{~W} \mathrm{~m}^{-2}$ at most sites, which indicated more cooling effects on the whole earth-atmosphere system due to large aerosol extinctions in the YRD. The DARF-TOA means were about $-20 \mathrm{~W} \mathrm{~m}^{-2}$ at the seven sites in July/August, which suggests weak cooling at that time. In contrast, the DARF-TOA values under clear conditions at Shenyang (urban area of northeastern China), Beijing (urban area of northern China) and Xianghe (rural area of northern China) showed a negative peak during June to August due to the large aerosol extinctions in the summer season (Zhao et al., 2015; Xia et al., 2016). As noted in Sect. 3.3, the SSA was low in July and August, and that was attributed to absorbing particles from biomass burning. Ding et al. (2016) found that large quantities of black carbon can be emitted from biomass burning in the YRD during the summer, and because these particles strongly absorb at infrared wavelengths, they can cause a heating up of the atmosphere, resulting in lower negative DARF-TOA. Indeed, the positive DARF-TOA values we found under clear conditions from April to October were mainly due to the effects of strongly absorbing particles; that is, the SSAs at $440 \mathrm{~nm}$ were $<0.80$, and they showed a strong decrease with wavelength (not shown here) when DARF-TOA values were positive. Moreover, strongly absorbing aerosol particles can heat the atmosphere column and the TOA at the same time.

\subsection{Aerosol type classification based on the aerosol optical properties}

In previous studies, aerosol types have sometimes been simply classified as dust (high AOD, low AE (Angström exponent)) and anthropogenic aerosols (high AOD, high AE) (H. Z. Che et al., 2009; H. Che et al., 2009; Wang et al., 2010). However, aerosol direct radiative forcing is affected by the absorptivity of aerosol and the underlying surface conditions (Haywood and Shine, 1995), and there are advantages to the better characterization of the aerosol populations. For example, the classification of ground-based aerosol types can be used to compare and validate aerosol types in chemical transport models and satellites retrievals (J. Lee et al., 2010). Thus, it is advantageous to categorize aerosols as absorbing or non-absorbing based on ground-based optical parameters, including SSA, fine-mode fraction of AOD, and EAE etc. In this study, we used the SSA, FMF and EAE values to classify the fine-mode and coarse-mode particles from each site into eight groups of particles following the method of Zheng et al. (2017). The eight types of particles were (I) highly absorbing fine-mode particles (AE $>1.2$, SSA $\leq 0.85$ ); (II) moderately absorbing fine-mode particles $(\mathrm{AE}>1.2,0.85 \leq \mathrm{SSA}<0.9)$; (III) slightly absorbing finemode particles (AE $>1.2,0.9 \leq \mathrm{SSA}<0.95$ ); (IV) weakly absorbing fine-mode particles (AE $>1.2$, SSA $>0.95)$; (V) mixed-absorbing particles $(0.6 \leq \mathrm{AE}<1.2, \quad \mathrm{SSA} \leq 0.95)$; (VI) mixed slightly absorbing particles $(0.6 \leq \mathrm{AE}<1.2$, SSA > 0.95); (VII) strongly absorbing coarse-mode particles - mainly dust ( $\mathrm{AE} \leq 0.6$, SSA $\leq 0.95)$; and (VIII) weakly absorbing coarse-mode particles ( $\mathrm{AE} \leq 0.6, \mathrm{SSA}>0.95$ ).

From Figs. 8 and 9, one can see that the absorbing finemode particles (Type I, II and III) accounted for $\sim 30$ to $50 \%$ of the aerosol in the YRD region with the FMF $\sim 0.86-0.94 \%$. The percentage of highly absorbing fineparticles (Type I) was obviously larger at Hangzhou $(\sim 8 \%)$ (FMF $\sim 0.90)$ than the smaller city sites $(\sim 2-3 \%$ ), and at 

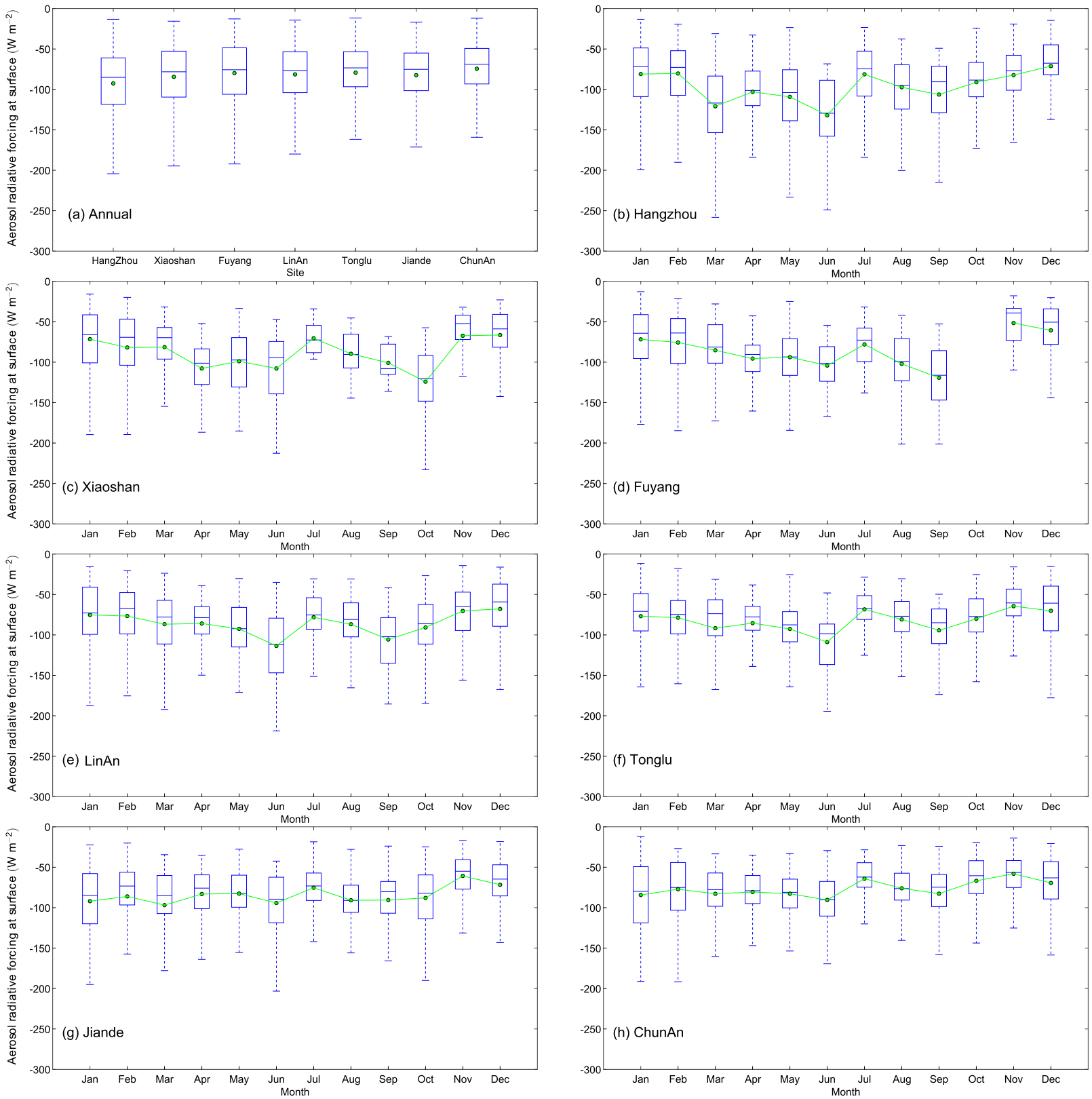

Figure 6. (a) Annual variations of monthly mean direct aerosol radiative forcing (50-80 SZA) at the bottom of the atmosphere over (b) Hangzhou, (c) Xiaoshan, (d) Fuyang, (e) LinAn, (f) Tonglu, (g) Jiande and (h) ChunAn. See Fig. 3 for an explanation of the symbols.

the ChunAn rural site, the percentage of Type I particles was only $\sim 0.16 \%$ (FMF $\sim 0.91)$. This indicates that there were greater emissions of strong absorbing aerosols from sources such as biomass burning and/or urban/industrial activities at the urban site compared with the rural one. The proportion of weakly absorbing fine-mode particles (Type IV) varied from $\sim 20$ to $30 \%$ for all sites, and the FMF varies from 0.89 to $\sim 0.95$ at the same time, which suggests that the second largest aerosol type in the area is weakly absorbing finemode particles. The percentage of mixed absorbing particles (Type V) was about $\sim 25-26 \%$ both at Hangzhou and the rural ChunAn site, which is slightly higher than that at small city sites $(\sim 10-20 \%)$ where the FMF of these particles was $\sim 0.81-0.89$. The higher FMF at Hangzhou was probably due to the complex aerosol emission sources that impact this megacity, while at ChunAn, which is surrounded by mountains, the basin topography promotes particle mixing. The mixed slightly absorbing particles (Type VI) showed the highest percentage of total aerosols at Fuyang $(18.05 \%)$ and ChunAn (15.32\%), and the FMF of this group varied from 0.84 to 0.91 at all sites. The contribution of Type VI mixed slightly absorbing particles at Hangzhou was $\sim 11.49 \%$, and 

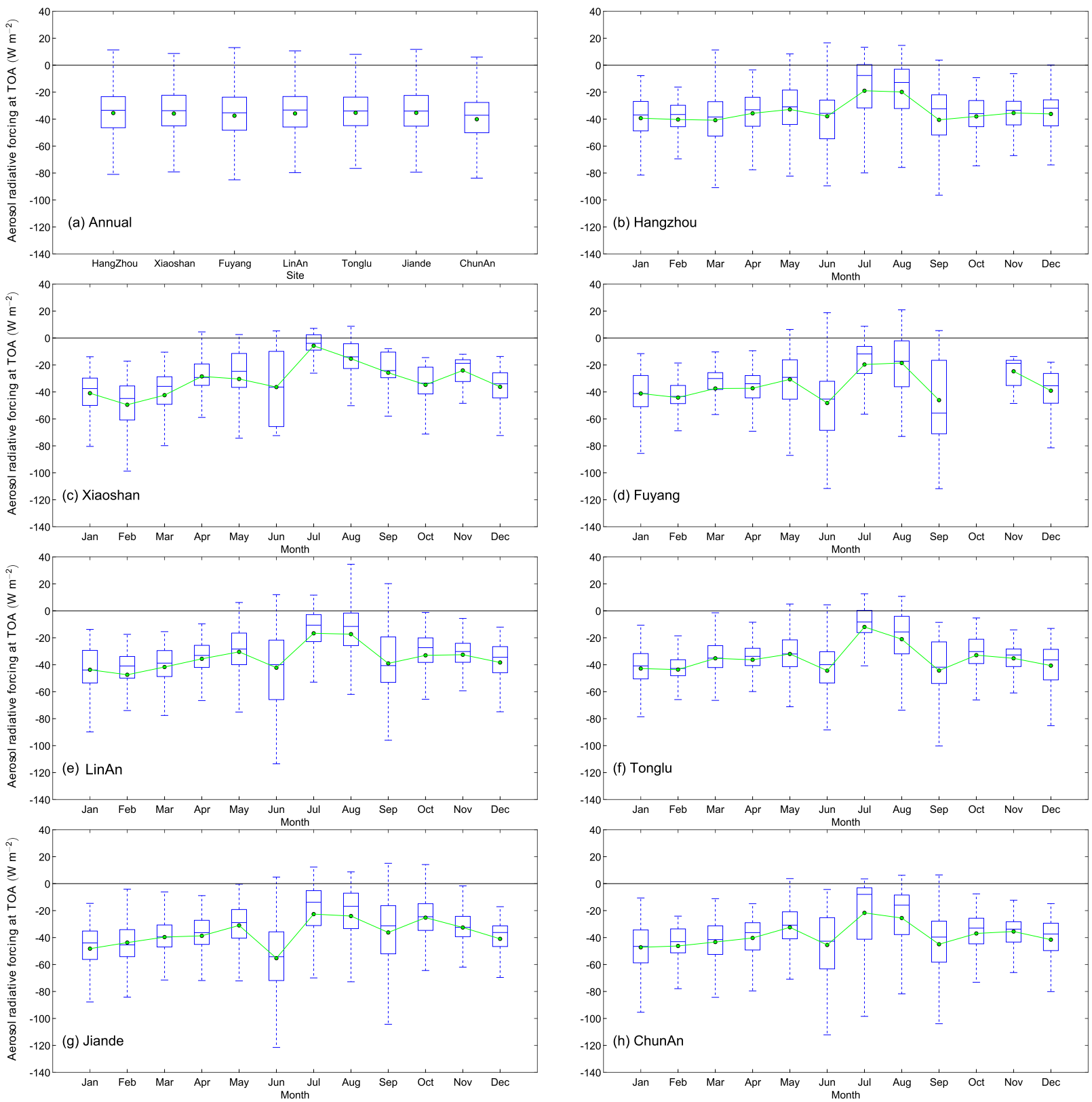

Figure 7. (a) Annual variations in the monthly mean direct aerosol radiative forcing (50-80 SZA) at the top of the atmosphere (TOA) at (b) Hangzhou, (c) Xiaoshan, (d) Fuyang, (e) LinAn, (f) Tonglu, (g) Jiande and (h) ChunAn. See Fig. 3 for an explanation of the symbols.

the FMF (0.86) there was not as high as at ChunAn (0.91). The proportion of strongly absorbing coarse-mode particles - mainly dust (Group VII) - was only $\sim 1.04 \%$ of the total particle count at Hangzhou, while at the other sites the percent abundances were $<1 \%$, and the FMF for these particles was $\sim 0.50-0.63$ at all sites. These patterns show that the YRD region is different from regions in northern China, including Beijing, where dust particles contribute significantly to the coarse-mode absorption (Zheng et al., 2017). The percentage of weakly absorbing coarse-mode particles (Group VIII) at all sites was $<0.54 \%$, which shows that this aerosol type was rare. In addition, the FMF of Group VIII particles was $0.5-0.8$, with large uncertainties at all sites. Overall, this analysis of aerosol types shows that the aerosol absorption is relatively weak in the YRD region, and the fine mode makes up an especially large contribution of the absorbing particles at Hangzhou.

\subsection{Discussion}

Compared with previous studies on the climatology of aerosol microphysical and optical properties in China, large 

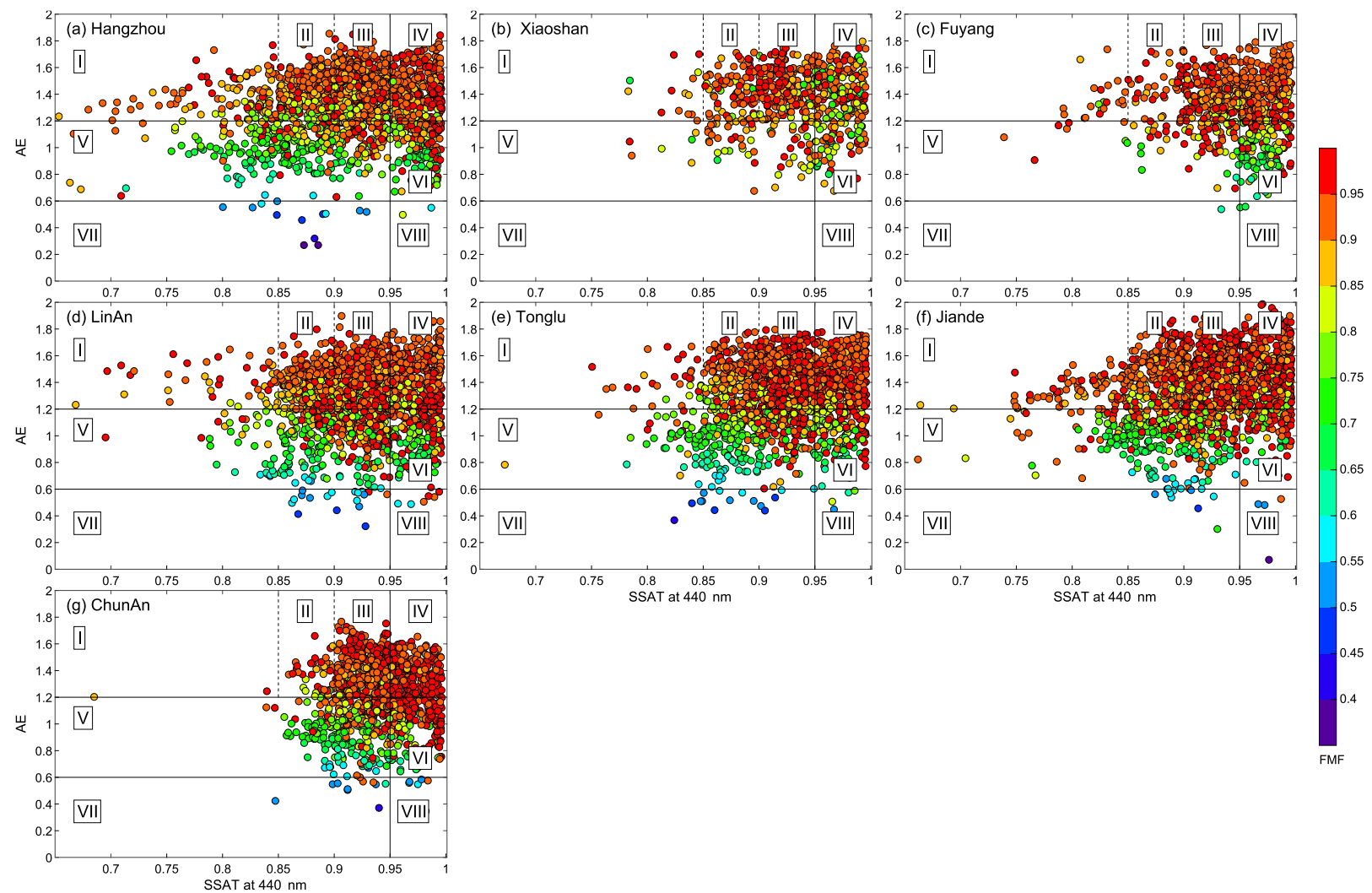

Figure 8. The aerosol type classification using SSA as a function of $\mathrm{AE}_{440-870 \mathrm{~nm}}$ over (a) Hangzhou, (b) Xiaoshan, (c) Fuyang, (d) LinAn, (e) Tonglu, (f) Jiande and (g) ChunAn. See text for description of groups I-VII.

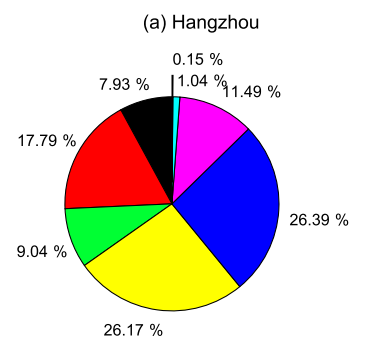

(e) Tonglu

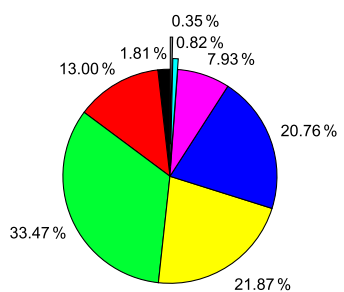

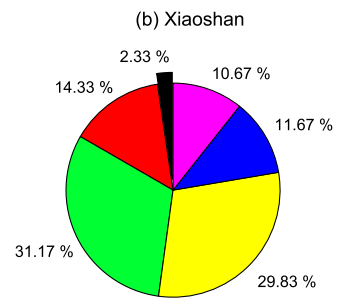

(f) Jiande

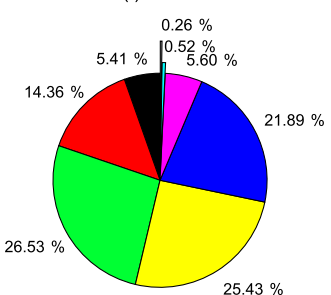

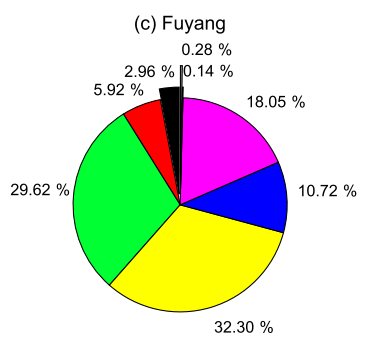

(g) ChunAn

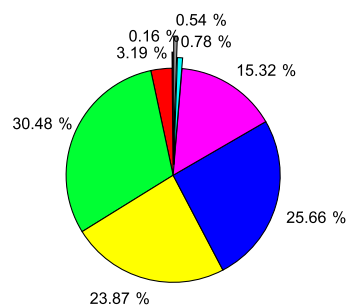

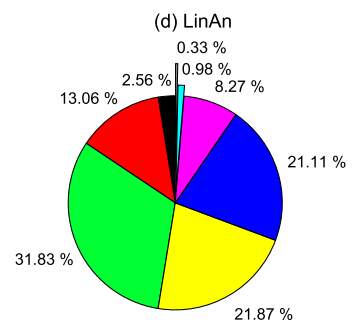

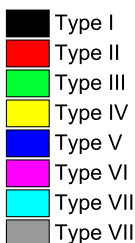

Figure 9. The distribution of the aerosol type classification over (a) Hangzhou, (b) Xiaoshan, (c) Fuyang, (d) LinAn, (e) Tonglu, (f) Jiande and (g) ChunAn. See text for description of types I-VII.

volumes and effective radii of fine-mode aerosol, as well as high AODs at $440 \mathrm{~nm}$, were found at most sites in June and September but not in July or August. This is remarkably different from studies conducted in northeastern/northern
China, where these properties showed the maximum values in July or August (Eck et al., 2005; Zhao et al., 2013; H. Che et al., 2015). This reflects the distinctive climatology of aerosol microphysical and optical properties in the YRD re- 
gion of eastern China. This information on the distributions and variations of aerosol microphysical and optical properties obtained in our study should be taken into account in the validation of satellite retrievals and aerosol modeling studies in the future.

The $\mathrm{AOD}_{440 \mathrm{~nm}}$ values in our study $(0.71-0.76)$ are similar to other urban areas of China, such as Shenyang (0.75), Beijing (0.76), Tianjin (0.74), Shanghai (0.70) and Hefei (0.69) (Pan et al., 2010; He et al., 2012; Zhao et al., 2013; H. Che et al., 2015; Liu et al., 2017). This indicates that high aerosol loadings caused by anthropogenic activities occur over many urban, suburban and even rural areas of eastern China. The $\mathrm{AOD}_{440 \mathrm{~nm}}$ at the rural ChunAn site $(\sim 0.68)$ is $\sim 2-6$ times higher than in other rural sites in China, such as Longfengshan (0.35; northeastern China), Xinglong (0.28, northern China), Akedala (0.20, northwestern China) and ShangriLa (0.11, southwestern China) (Wang et al., 2010; Che et al., 2011; Zhu et al., 2014; H. Che et al., 2015). Therefore, strong aerosol effects on light extinction occur not only in urban areas but also in much or possibly all of the YRD. The $\mathrm{SSA}_{440 \mathrm{~nm}}$ in our study ranged from 0.91 to 0.94 , which is similar to other regions of China, such as Wuhan (0.92), Beijing (0.89) and Xinglong (0.92) (L. C. Wang et al., 2015; Xin et al., 2014; Zhu et al., 2014); this suggests aerosol particles in the YRD are slight to relatively strong absorbers of violet/indigo wavelengths.

Although the AAE has been used as an indicator of the dominant absorbing aerosol type, the SSA, FMF and EAE were also used to classify the absorption characteristics of fine-mode and coarse-mode particles. It should also be mentioned that uncertainties in the AAE calculations due to uncertainties in the SSAs may have contributed to the observed differences between sites (Bergstrom et al., 2007; Giles et al., 2011). Ideally, the aerosol physical and chemical characteristic measurements will be combined at some point to more definitively classify the aerosol types. In addition, even though Zhuang et al. (2017) pointed that the DARFs are not very sensitive to vertical profiles under clear-sky conditions, future research should take into account the vertical distributions of aerosols to more accurately assess the direct aerosol radiative forcing effects.

The useful observations at most sites in this study were made on 439-562 days, but smaller numbers of observation were made in Xiaoshan and Fuyang because of instrument failures, on 180 and 217 days, respectively. There were fewer than 15 days of useful data for October and November at Fuyang and for June, July, September and November at Xiaoshan. While the available data do provide insights into the aerosol characteristics at the sites, more extended observations should be conducted at the two sites in future.

\section{Conclusions}

A detailed study of aerosol microphysical and optical properties retrieved from synchronous ground-based sun photometer observations was conducted at seven sites in the Yangtze River Delta region of eastern China from 2011 to 2015. The aerosols were classified into eight types, and calculations were made for the direct aerosol radiative forcing (DARF) at the top and bottom of the atmosphere. The conclusions of the study can be summarized as follows.

A relatively homogeneous distribution of aerosol microphysical properties was found for a megacity, five small cities and a rural site in the YRD region. High particle volumes of coarse-mode aerosol occurred in March to May, which reflects the existence of large mineral particles from springtime dust storms. High volumes and large effective radii of fine-mode aerosol in June and September were found at most sites, and this was attributed to aerosol hygroscopicity and cloud processing. The low volumes and large bandwidth of both fine-mode and coarse-mode aerosol found in July and August at all sites was explained by the wet removal of coarse particles during the heavy precipitation in June and the influences of subtropical anticyclones in summer.

The $\mathrm{AOD}_{440 \mathrm{~nm}}$ generally decreased from the east coast ( 0.76 - Hangzhou) to the inland areas towards the west $(0.68$ - ChunAn), and this can be explained by anthropogenic impacts of the more urbanized regions in the east YRD region. The $\mathrm{AOD}_{440 \mathrm{~nm}}$ values at urban and rural sites of YRD were $0.68-0.76$, and the fine-mode fraction was $\sim 0.90$, which indicates that fine-mode particles were more important than the coarse mode for the light extinction. The difference in AODs between the urban and rural sites was less than $10 \%$, and this can be explained by somewhat stronger effects of anthropogenic activities in the urban area. The monthly averaged AODs at $440 \mathrm{~nm}$ showed peaks in June and September that resulted from increases in fine-mode aerosol particles. However, AODs at $440 \mathrm{~nm}$ in July and August were the lowest over the year, and this was related to conditions favorable for aerosol dispersion. The mean extinction Angström exponent was $>1.20$ all year, indicating that small particles were predominant in the region. The SSAs at $440 \mathrm{~nm}$ varied from 0.91 to 0.94 at the urban and rural sites, indicating that the aerosol particles were moderately absorbing, and this is almost surely a result of impacts from the high industrial emissions and other anthropogenic activities in the region. There was an obvious wavelength dependence for the SSA in July and August, and aerosols absorbed most strongly at infrared wavelengths. The AAODs at $440 \mathrm{~nm}$ at the seven sites were $\sim 0.04-0.06$, which suggests that absorbing aerosols are distributed more or less homogeneously throughout the YRD region. The averaged $\mathrm{AAOD}_{440 \mathrm{~nm}}$ at Hangzhou is about 0.02 higher than that at ChunAn, which indicates that the relative proportion of absorbing particles in the urban area is larger compared with the rural area. The $\mathrm{AAOD}_{440 \mathrm{~nm}}$ in winter was $<0.05$, which suggests that light absorption by the particles 
was low compared with the other seasons. The geographical variability in the distributions of the AAEs suggests that the absorbing aerosols possibly have different optical characteristics related to the local emission sources in the YRD.

The DARF-BOA at Hangzhou was $\sim-20 \mathrm{~W} \mathrm{~m}^{-2}$ lower than that at the rural ChunAn site, which shows stronger aerosol cooling at the megacity. The monthly DARF-BOA was strongly negative in June due to the high aerosol extinction and especially the high fine-mode volume. The DARFTOAs under clear conditions were $<-40 \mathrm{~W} \mathrm{~m}^{-2}$ but were about $-20 \mathrm{~W} \mathrm{~m}^{-2}$ in July/August, which suggests weaker cooling in midsummer. The DARF-TOAs were positive from April to October when the $\mathrm{SSA}_{440 \mathrm{~nm}}<0.80$, and the greater effects at shorter wavelengths were likely due to emissions of carbonaceous particles from the burning of crop residues.

The SSA, FMF, and EAE values were used to classify the particles as absorbing or non-absorbing. Relatively large emissions of strongly absorbing aerosols in the Hangzhou urban area was the result of biomass burning and/or urban/industrial activities. The aerosol type classification showed overall that the aerosol absorption is weak to moderate in the YRD, and the fine mode has a large contribution to the higher percentage of absorbing particles at the Hangzhou site.

Data availability. The datasets can be obtained from the corresponding author upon request.

Supplement. The supplement related to this article is available online at: https://doi.org/10.5194/acp-18-405-2018-supplement.

Competing interests. The authors declare that they have no conflict of interest.

Special issue statement. This article is part of the special issue "Regional transport and transformation of air pollution in eastern China”. It is not associated with a conference.

Acknowledgements. This work was supported by a grant from the National Key R \& D Program Pilot Projects of China (2016YFA0601901), the National Natural Science Foundation of China (41590874, 41475138 \& 41375153), the Natural Science Foundation of Zhejiang Province (LY16010006), the CAMS Basis Research Project (2016Z001 \& 2014R17), the Climate Change Special Fund of CMA (CCSF201504), the Special Project of Doctoral Research supported by Liaoning Provincial Meteorological Bureau (D201501), the Hangzhou Science and Technology Innovative project (20150533B17) and the European Union Seventh Framework Programme (FP7/2007-2013) under grant agreement no. 262254. The authors would like to thank the three anonymous reviewers and the editor for their constructive suggestions and comments.

Edited by: Zhanqing Li

Reviewed by: three anonymous referees

\section{References}

Ackerman, P. and Toon, O. B.: Absorption of visible radiation in atmosphere containing mixtures of absorbing and nonabsorbing particles, Appl. Optics, 20, 3661-3668, 1981.

Albrecht, B.: Aerosols, cloud microphysics, and fractional cloudiness, Science, 245, 1227-1230, 1989.

Bergstrom, R. W., Pilewskie, P., Russell, P. B., Redemann, J., Bond, T. C., Quinn, P. K., and Sierau, B.: Spectral absorption properties of atmospheric aerosols, Atmos. Chem. Phys., 7, 5937-5943, https://doi.org/10.5194/acp-7-5937-2007, 2007.

Cao, J., Shen, Z., Chow, J. C., Qi, G., and Watson, J. G.: Seasonal variations and sources of mass and chemical composition for $\mathrm{PM}_{10}$ aerosol in Hangzhou, China, Particuology, 7, 161-168, https://doi.org/10.1016/j.partic.2009.01.009, 2009.

Charlson, R. J., Schwartz, S. E., Hales, J. M., Cess, D., Coakley, J. A., and Hansen, J. E.: Climate forcing by anthropogenic aerosols, Science, 255, 423-430, 1992.

Che, H., Zhang, X., Chen, H., Damiri, B., Goloub, P., Li, Z., Zhang, X., Wei, Y., Zhou, H., Dong, F., Li, D., and Zhou, T.: Instrument calibration and aerosol optical depth (AOD) validation of the China Aerosol Remote Sensing Network (CARSNET), J. Geophys. Res., 114, D03206, https://doi.org/10.1029/2008JD011030, 2009.

Che, H., Wang, Y., Sun, J., and Zhang, X.: Assessment of In-situ Langley Calibration of CE-318 Sunphotometer Mt. Waliguan Observatory, China, SOLA, 7, 89-92, https://doi.org/10.2151/sola.2011-023, 2011.

Che, H., Zhang, X.-Y., Xia, X., Goloub, P., Holben, B., Zhao, H., Wang, Y., Zhang, X.-C., Wang, H., Blarel, L., Damiri, B., Zhang, R., Deng, X., Ma, Y., Wang, T., Geng, F., Qi, B., Zhu, J., Yu, J., Chen, Q., and Shi, G.: Ground-based aerosol climatology of China: aerosol optical depths from the China Aerosol Remote Sensing Network (CARSNET) 2002-2013, Atmos. Chem. Phys., 15, 7619-7652, https://doi.org/10.5194/acp15-7619-2015, 2015.

Che, H. Z., Zhang, X. Y., Alfraro, S., Chatenet, B., Gomes, L., and Zhao, J. Q.: Aerosol optical properties and its radiative forcing over Yulin, China in 2001 and 2002, Adv. Atmos. Sci., 26, 564576, https://doi.org/10.1007/s00376-009-0564-4, 2009.

Che, H. Z., Xia, X. A., Zhu, J., Wang, H., Wang, Y. Q., Sun, J. Y., Zhang, X. C., Zhang, X. Y., and Shi, G. Y.: Aerosol optical properties under the condition of heavy haze over anurban site of Beijing, China, Environ. Sci. Pollut. R., 22, 1043-1053, https://doi.org/10.1007/s11356-014-3415-5, 2014.

Che, H. Z., Xia, X. A., Zhu, J., Wang, H., Wang, Y. Q., Sun, J. Y., Zhang, X. C., Zhang, X. Y., and Shi, G. Y.: Aerosol optical properties under the condition of heavy haze over an urban site of Beijing, China, Environ. Sci. Pollut. R., 22, 1043-1053, 2015.

Cheng, T., Liu, Y., Lu, D., Xu, Y., and Li, H.: Aerosol properties and radiative forcing in Hunshan Dake desert, northern China, Atmos. Environ., 40, 2169-2179, 2006. 
Cheng, T. T., Xu, C., Duan, J. Y., Wang, Y. F., Leng, C. P., Tao, J., Che, H. Z., He, Q. S., Wu, Y. F., Zhang, R. J., Li, X., Chen, J. M., Kong, L. D., and Yu, X. N.: Seasonal variation and difference of aerosol optical properties in columnar and surface atmospheres over Shanghai, Atmos. Environ., 123, 315-326, 2015.

Ding, A. J., Fu, C. B., Yang, X. Q., Sun, J. N., Zheng, L. F., Xie, Y. N., Herrmann, E., Nie, W., Petäjä, T., Kerminen, V.-M., and Kulmala, M.: Ozone and fine particle in the western Yangtze River Delta: an overview of $1 \mathrm{yr}$ data at the SORPES station, Atmos. Chem. Phys., 13, 5813-5830, https://doi.org/10.5194/acp13-5813-2013, 2013a.

Ding, A. J., Fu, C. B., Yang, X. Q., Sun, J. N., Petäjä, T., Kerminen, V.-M., Wang, T., Xie, Y., Herrmann, E., Zheng, L. F., Nie, W., Liu, Q., Wei, X. L., and Kulmala, M.: Intense atmospheric pollution modifies weather: a case of mixed biomass burning with fossil fuel combustion pollution in eastern China, Atmos. Chem. Phys., 13, 10545-10554, https://doi.org/10.5194/acp-13-105452013, 2013b.

Ding, A. J., Huang, X., Nie, W., Sun, J. N., Kerminen, V. M., Petäjä, T., Su, H., Cheng, Y. F., Yang, X. Q., Wang, M. H., Chi, X. G., Wang, J. P., Virkkula, A., Guo, W. D., Yuan, J., Wang, S. Y., Zhang, R. J., Wu, Y. F., Song, Y., Zhu, T., Zilitinkevich, S., Kulmala, M., and Fu, C. B.: Enhanced haze pollution by black carbon in megacities in China, Geophys. Res. Lett., 43, 2873-2879, https://doi.org/10.1002/2016GL067745, 2016.

Duan, J. and Mao, J.: Study on the distribution and variation trends of atmospheric aerosol optical depth over the Yangtze River Delta, Acta Scien. Circum., 27, 537-543, 2007.

Dubovik, O. and King, M. D.: A flexible inversion algorithm for retrieval of aerosol optical properties from sun and sky radiance measurements, J. Geophys. Res., 105, 20673-20696, https://doi.org/10.1029/2000JD900282, 2000.

Dubovik, O., Smirnov, A., Holben, B. N., King, M. D., Kaufman, Y. J., Eck, T. F., and Slutsker, I.: Accuracy assessments of aerosol optical properties retrieved from Aerosol Robotic Network (AERONET) Sun and sky radiance measurements, J. Geophys. Res., 105, 9791-9806, 2000.

Dubovik, O., Holben, B. N., Eck, T. F., Smirnov, A., Kaufman, Y. J., King, M. D., Tanre, D., and Slutsker, I.: Variability of absorption and optical properties of key aerosol types observed in worldwide locations, J. Atmos. Sci., 59, 590-608, 2002.

Dubovik, O., Sinyuk, A., Lapyonok, T., Holben, B. N., Mishchenko, M., Yang, P., Eck, T. F., Volten, H., Munoz, O., Veihelmann, B., van der Zande, W. J., Leon, J. F., Sorokin, M., and Slutsker, I.: Application of spheroid models to account for aerosol particle nonsphericity in remote sensing of desert dust, J. Geophys. Res.Atmos., 111, D11208, https://doi.org/10.1029/2005JD006619, 2006.

Dubuisson, P., Buriez, J. C., and Fouquart, Y.: High spectral resolution solar radiative transfer in absorbing and scattering media, application to the satellite simulation, J. Quant. Spectrosc. Ra., 55, 103-126, https://doi.org/10.1016/0022-4073(95)00134-4, 1996.

Eck, T. F., Holben, B. N., Reid, J. S., Dubovik, O., Smirnov, A., O'Neill, N. T., Slutsker, I., and Kinne, S.: Wavelength dependence of the optical depth of biomass burning, urban, and desert dust aerosols, J. Geophys. Res., 104, 31333-31349, 1999.

Eck, T. F., Holben, B. N., Dubovik, O., Smirnov, A., Goloub, P., Chen, H. B., Chatenet, B., Gomes, L., Zhang, X. Y., Tsay, S. C., Ji, Q., Giles, D., and Slutsker, I.: Columnar aerosol opti- cal properties at AERONET sites in central eastern Asia and aerosol transport to the tropical Mid-Pacific, J. Geophys. Res., 110, D06202, https://doi.org/10.1029/2004JD005274, 2005.

Eck, T. F., Holben, B. N., Sinyuk, A., Pinker, R. T., Goloub, P., Chen, H., Chatenet, B., Li, Z., Singh, R. P., Tripathi, S. N., Reid, J. S., Giles, D. M., Dubovik, O., O'Neill, N. T., Smirnov, A., Wang, P., and Xia, X.: Climatological aspects of the optical properties of fine/coarse mode aerosol mixtures, J. Geophys. Res., 115, D19205, https://doi.org/10.1029/2010JD014002, 2010.

Eck, T. F., Holben, B. N., Reid, J. S., Giles, D. M., Rivas, M. A., Singh, R. P., Tripathi, S. N., Bruegge, C. J., Platnick, S., Arnold, G. T., Krotkov, N. A., Carn, S. A., Sinyuk, A., Dubovik, O., Arola, A., Schafer, J. S., Artaxo, P., Smirnov, A., Chen, H., and Goloub, P.: Fog- and Cloud induced aerosol modification observed by the Aerosol Robotic Network (AERONET), J. Geophys. Res., 117, D07206, https://doi.org/10.1029/2011JD016839, 2012.

Estellés, V., Campanelli, M., Utrillas, M. P., Expósito, F., and Martínez-Lozano, J. A.: Comparison of AERONET and SKYRAD4.2 inversion products retrieved from a Cimel CE318 sunphotometer, Atmos. Meas. Tech., 5, 569-579, https://doi.org/10.5194/amt-5-569-2012, 2012.

Fu, Q., Zhuang, G., Wang, J., Xu, C., Huang, K., Li, J., Hou, B., Lu, T., and Streets, D. G.: Mechanism of formation of the heaviest pollution episode ever recorded in the Yangtze River Delta, China, Atmos. Environ., 42, 2023-2036, 2008.

Fu, X., Wang, S. X., Cheng, Z., Xing, J., Zhao, B., Wang, J. D., and Hao, J. M.: Source, transport and impacts of a heavy dust event in the Yangtze River Delta, China, in 2011, Atmos. Chem. Phys., 14, 1239-1254, https://doi.org/10.5194/acp14-1239-2014, 2014.

García, O. E., Díaz, J. P., Expósito, F. J., Díaz, A. M., Dubovik, O., Dubuisson, P., Roger, J.-C., Eck, T. F., Sinyuk, A., Derimian, Y., Dutton, E. G., Schafer, J. S., Holben, B. N., and García, C. A.: Validation of AERONET estimates of atmospheric solar fluxes and aerosol radiative forcing by groundbased broadband measurements, J. Geophys. Res., 113, D21207, https://doi.org/10.1029/2008JD010211, 2008.

García, O. E., Díaz, J. P., Expósito, F. J., Díaz, A. M., Dubovik, O., and Derimian, Y.: Aerosol radiative forcing: AERONET based estimates, climate Models, edited by: Druyan, L., ISBN: 978953-51-0135-2, InTech, 2012.

Giles, D. M., Holben, B. N., Tripathi, S. N., Eck, T. F., Newcomb, W. W., Slutsker, I., Dickerson, R. R., Thompson, A. M., Mattoo, S., and Wang, S. H.: Aerosol properties over the Indo-Gangetic Plain: A mesoscale perspective from the TIGERZ experiment, J. Geophys. Res.-Atmos., 116, D18203, https://doi.org/10.1029/2011JD015809, 2011.

Giles, D. M., Holben, B. N., Eck, T. F., Sinyuk, A., Smirnov, A., Slutsker, I., Dickerson, R. R., Thompson, A. M., and Schafer, J. S.: An analysis of AERONET aerosol absorption properties and classifications representative of aerosol source regions, J. Geophys. Res.-Atmos., 117, 127-135, 2012.

Goloub, P., Li, Z., Dubovik, O., Blarel, L., Podvin, T., Jankowiak, I., Lecoq, R., Deroo, C., Chatenet, B., and Morel, J. P.: PHOTONS/AERONET sunphotometer network overview: description, activities, results, Fourteenth International Symposium on Atmospheric and Ocean Optics/Atmospheric Physics, 69360V69360V-69315, 2007. 
Hansen, J., Sato, M., Ruedy, R., Lacis, A., and Oinas, V.: Global warming in the twenty-first century: an alternative scenario, $\mathrm{P}$. Natl. Acad. Sci. USA, 97, 9875-9880, 2000.

Haywood, J. M. and Shine, K. P.: The effect of anthropogenic sulfate and soot aerosol on the clear sky planetary radiation budget, Geophys. Res. Lett., 22, 603-606, https://doi.org/10.1029/95GL00075, 1995.

He, Q., Li, C., Geng, F., Yang, H., Li, P., Li, T., Liu, D., and Pei, Z.: Aerosol optical properties retrieved from Sun photometer measurements over Shanghai, China, J. Geophys. Res.-Atmos., 117, D16204, https://doi.org/10.1029/2011JD017220, 2012.

Holben, B. N., Eck, T. F., Slutsker, I., Tanré, D., Buis, J. P., Setzer, A., Vermote, E., Reagan, J. A., Kaufman, Y. J., Nakajima, T., Lavenu, F., Jankowiak, I., and Smirnov, A.: AERONET - A Federated Instrument Network and Data Archive for Aerosol Characterization, Remote Sens. Environ., 66, 1-16, https://doi.org/10.1016/S0034-4257(98)00031-5, 1998.

Holben, B. N., Tanré, D., Smirnov, A., Eck, T. F., Slutsker, I., Abuhassan, N., Newcomb, W. W., Schafer, J. S., Chatenet, B., and Lavenu, F.: An emerging ground-based aerosol climatology: Aerosol optical depth from AERONET, J. Geophys. Res.Atmos., 106, 12067-12097, 2001.

Holben, B. N., Kim, J., Sano, I., Mukai, S., Eck, T. F., Giles, D. M., Schafer, J. S., Sinyuk, A., Slutsker, I., Smirnov, A., Sorokin, M., Anderson, B. E., Che, H., Choi, M., Crawford, J. E., Ferrare, R. A., Garay, M. J., Jeong, U., Kim, M., Kim, W., Knox, N., Li, Z., Lim, H. S., Liu, Y., Maring, H., Nakata, M., Pickering, K. E., Piketh, S., Redemenn, J., Reid, J. S., Salinas, S., Seo, S., Tan, F., Tripathi, S. N., Toon, O. B., and Xiao, Q.: An overview of meso-scale aerosol processes, comparison and validation studies from DRAGON networks, Atmos. Chem. Phys. Discuss., https://doi.org/10.5194/acp-2016-1182, in review, 2017.

Huang, X., Ding, A., Liu, L., Liu, Q., Ding, K., Niu, X., Nie, W., Xu, Z., Chi, X., Wang, M., Sun, J., Guo, W., and Fu, C.: Effects of aerosol-radiation interaction on precipitation during biomassburning season in East China, Atmos. Chem. Phys., 16, 10063 10082, https://doi.org/10.5194/acp-16-10063-2016, 2016.

Intergovernmental Panel on Climate Change (IPCC): Climate Change 2013, The Scientific Basis, Cambridge University Press, New York, NY, USA, 2013.

Kaufman, Y. J., Tanré, D., and Boucher, O. A.: satellite view of aerosols in the climate system, Nature, 419, 215-223, 2002.

Lacis, A. A. and Oinas, V.: A description of the correlated kdistribution method for modeling nongray gaseous absorption, thermal emission, and multiple scattering in vertically inhomogeneous atmospheres, J. Geophys. Res., 96, 9027-9063, 1991.

Lack, D. A. and Cappa, C. D.: Impact of brown and clear carbon on light absorption enhancement, single scatter albedo and absorption wavelength dependence of black carbon, Atmos. Chem. Phys., 10, 4207-4220, https://doi.org/10.5194/acp10-4207-2010, 2010.

Lee, K. H., Li, Z., Cribb, M. C., Liu, J., Wang, L., Zheng, Y., Xia, X., Chen, H., and Li, B.: Aerosol optical depth measurements in eastern China and a new calibration method, J. Geophys. Res., 115, 4038-4044, https://doi.org/10.1029/2009JD012812, 2010.

Lee, J., Kim, J., Song, C. H., Kim, S. B., Chun, Y., Sohn, B. J., and Holben, B. N.: Characteristics of aerosol types from AERONET sunphotometer measurements, Atmos. Environ., 44, 3110-3117, https://doi.org/10.1016/j.atmosenv.2010.05.035, 2010.
Li, J., Carlson, B. E., and Lacis, A. A.: Using single-scattering albedo spectral curvature to characterize East Asian aerosol mixtures, J. Geophys. Res.-Atmos., 120, 2037-2052, 2015.

Li, S., Wang, T., Xie, M., Han, Y., and Zhuang, B.: Observed aerosol optical depth and angstrom exponent in urban area of Nanjing, China, Atmos. Environ., 123, 350-356, 2015.

Li, W. J., Shao, L. Y., and Buseck, P. R.: Haze types in Beijing and the influence of agricultural biomass burning, Atmos. Chem. Phys., 10, 8119-8130, https://doi.org/10.5194/acp-108119-2010, 2010.

Li, W. J., Sun, J. X., Xu, L., Shi, Z. B., Riemer, N., Sun, Y. L., Fu, P. Q., Zhang, J. C., Lin, Y. T., Wang, X. F., Shao, L. Y., Chen, J. M., Zhang, X. Y., Wang, Z. F., and Wang, W. X.: A conceptual framework for mixing structures in individual aerosol particles, J. Geophys. Res., 121, 13205-13798, https://doi.org/10.1002/2016JD025252, 2016.

Li, Z., Lau, W. K.-M., Ramanathan, V., Wu, G., Ding, Y., Manoj, M. G., Liu, J., Qian, Y., Li, J., Zhou, T., Fan, J., Rosenfeld, D., Ming, Y., Wang, Y., Huang, J., Wang, B., Xu, X., Lee, S.S., Cribb, M., Zhang, F., Yang, X., Takemura, T., Wang, K., Xia, X., Yin, Y., Zhang, H., Guo, J., Zhai, P. M., Sugimoto, N., Babu, S. S., and Brasseur, G. P.: Aerosol and monsoon climate interactions over Asia, Rev. Geophys., 54, 866-929, https://doi.org/10.1002/2015RG000500, 2016.

Li, Z. Q., Eck, T., Zhang, Y., Zhang, Y. H., Li, D. H., Li, L., Xu, H., Hou, W. Z., Lv, Y., Goloub, P., and Gu, X. F.: Observations of residual submicron fine aerosol particles related to cloud and fog processing during a major pollution event in Beijing, Atmos. Environ., 86, 187-192, 2014.

Liu, Q., Ding, W. D., Xie, L., Zhang, J. Q., Zhu, J., Xia, X. A., Liu, D. Y., Yuan, R. M., and Fu, Y. F.: Aerosol properties over an urban site in central East China derived from ground sunphotometer measurements, Sci. China Earth Sci., 60, 297-314, https://doi.org/10.1007/s11430-016-0104-3, 2017.

Myhre, G.: Consistency between satellite-derived and modeled estimates of the direct aerosol effect, Science, 325, 187-190, 2009.

Nakajima, T. and Tanaka, M.: Algorithms for radiative intensity calculations in moderately thick atmospheres using a truncation approximation, J. Quant. Spectrosc. Ra., 40, 51-69, 1988.

Pan, L., Che, H., Geng, F., Xia, X., Wang, Y., Zhu, C., Chen, M., Gao, W., and Guo, J.: Aerosol optical properties based on ground measurements over the Chinese Yangtze Delta Region, Atmos. Environ., 44, 2587-2596, 2010.

Panicker, A. S., Lee, D. I., Kumkar, Y. V., Kim, D., Maki, M., and Uyeda, H.: Decadal climatological trends of aerosoloptical parameters over three different environments in South Korea, Int. J. Climatol., 33, 1909-1916, 2013.

Pappalardo, G., Amodeo, A., Apituley, A., Comeron, A., Freudenthaler, V., Linné, H., Ansmann, A., Bösenberg, J., D’Amico, G., Mattis, I., Mona, L., Wandinger, U., Amiridis, V., AladosArboledas, L., Nicolae, D., and Wiegner, M.: EARLINET: towards an advanced sustainable European aerosol lidar network, Atmos. Meas. Tech., 7, 2389-2409, https://doi.org/10.5194/amt7-2389-2014, 2014.

Roger, J.-C., Mallet, M., Dubuisson, P., Cachier, H., Vermote, E., Dubovik, O., and Despiau, S.: A synergetic approach for estimating the local direct aerosol forcing:applications to an urban zone during the ESCOMPTE experiment, J. Geophys. Res., 111, D13208, https://doi.org/10.1029/2005JD006361, 2006. 
Russell, P. B., Bergstrom, R. W., Shinozuka, Y., Clarke, A. D., DeCarlo, P. F., Jimenez, J. L., Livingston, J. M., Redemann, J., Dubovik, O., and Strawa, A.: Absorption Angstrom Exponent in AERONET and related data as an indicator of aerosol composition, Atmos. Chem. Phys., 10, 1155-1169, https://doi.org/10.5194/acp-10-1155-2010, 2010.

Saha, A. and Moorthy, K. K.: Impact of precipitation on aerosol spectral optical depth and retrieved size distributions: A case study, J. Appl. Meteorol., 43, 902-914, 2004.

Sanap, S. D. and Pandithurai, G.: Inter-annual variability of aerosols and its relationship with regional climate over Indian subcontinent, Int. J. Climatol., 35, 1041-1053, https://doi.org/10.1002/joc.4037, 2014.

Schwartz, S. E. and Andreae, M. O.: Uncertainty in climate change caused by aerosols, Science, 272, 1121-1122, 1996.

Shen X. J., Sun, J. Y., Zhang, X. Y., Zhang, Y. M., Zhang L., Che, H. C., Ma, Q. L., Yu, X. M., Yue, Y., and Zhang, Y. W.: Characterization of submicron aerosols and effect on visibility during a severe haze-fog episode in Yangtze River Delta, China, Atmos. Environ., 120, 307-316, 2015.

Smirnov, A., Holben, B. N., Eck, T. F., Dubovik, O., and Slutsker, I.: Cloud screening and quality control algorithmsfor the AERONET data base, Remote Sens. Environ., 73, 337-349, 2000.

Smirnov, A., Holben, B. N., Lyapustin, A., Slutsker, I., and Eck, T. F.: AERONET processing algorithms refinement, AERONET Workshop, 10-14 May 2004, El Arenosillo, Spain, 2004.

Sokolik, I. N. and Toon, O. B.: Incorporation of mineralogical composition into models of the radiative properties of mineral aerosol from UV to IR wavelengths, J. Geophys. Res., 104, 9423-9444, https://doi.org/10.1029/1998JD200048, 1999.

Solomon, S., Qin, D., Manning, M., Chen, Z., Marquis, M., Averyt, K. B., Tignor, M., and Miller, H. L. (Eds.): Climate change 2007: the physical science basis., Contribution of Working Group I to the Fourth Assessment Report of the Intergovernmental Panel on Climate Change. Cambridge University Press, Cambridge, United Kingdom and New York, USA, 2007.

Stamnes, K., Tsay, S. C., Wiscombe, W., and Jayaweera, K.: Numerically stable algorithm for discrete-ordinate-method radiative transfer in multiple scattering and emitting layered media, Appl. Optics, 27, 2502-2509, 1988.

Sun, T., Che, H., Qi, B., Wang, Y., Dong, Y., Xia, X., Wang, H., Gui, K., Zheng, Y., Zhao, H., Ma, Q., Du, R., and Zhang, X.: Aerosol optical characteristics and their vertical distributions under enhanced haze pollution events: effect of the regional transport of different aerosol types over eastern China, Atmos. Chem. Phys. Discuss., https://doi.org/10.5194/acp-2017-805, in review, 2017.

Sun, Y., Sun, X., Yin, Y., and Han, Y.: Observation Study of Aerosol over Mid-Western North China Plain in Autumn (October), Plateau Meteorology, 32, 1308-1320, https://doi.org/10.7522/j.issn.1000-0534.2012.00123, 2013 (in Chinese).

Takamura, T. and Nakajima, T.: Overview of SKYNET and its activities, Opt. Puray. Apl., 37, 3303-3308, 2004.

Tan, H., Wu, D., Deng, X., Bi, X., Li, F., and Deng, T.: Observation of aerosol optical depth over the Pearl River Delta, Acta Sci. Circum., 29, 1146-1155, 2009 (in Chinese).
Twomey, S. A., Piepgrass, M., and Wolfe, T. L.: An assessment of the impact of pollution on the global cloud albedo, Tellus, 36B, 356-366, 1984.

Wang, L. C., Gong, W., Xia, X. A., Zhu, J., Li, J., and Zhu, Z. M.: Long-term observations of aerosol optical properties at Wuhan, an urban site in Central China, Atmos. Environ., 101, 94-102, 2015.

Wang, P., Che, H. Z., Zhang, X. C., Song, Q. L., Wang, Y. Q., Zhang, Z. H., Dai, X., and Yu, D. J.: Aerosol opticalproperties of regional background atmosphere in Northeast China, Atmos. Environ., 44, 4404-4412, 2010.

Wang, S. and Zhang, C.: Spatial and temporal distribution of air pollutant emissions from open burning of crop residues in China, Sciencepaper Online, 3, 329-333, 2008 (in Chinese).

Wang, Z., Liu, D., Wang, Y., Wang, Z., and Shi, G.: Diurnal aerosol variations do affect daily averaged radiative forcing under heavy aerosol loading observed in Hefei, China, Atmos. Meas. Tech., 8, 2901-2907, https://doi.org/10.5194/amt-8-2901-2015, 2015.

Wehrli, C.: Calibration of filter radiometers for the GAW Aerosol Optical Depth network at Jungfraujoch and Mauna Loa, in: Proceedings of ARJ Workshop, SANW Congress, Davos, Switzerland, 70-71, 2002.

Xia, X., Li, Z., Holben, B., Wang, P., Eck, T., Chen, H., Cribb, M., and Zhao, Y.: Aerosol optical properties and radiative effects in the Yangtze Delta region of China, J. Geophys. Res., 112, D22S12, https://doi.org/10.1029/2007JD008859, 2007.

Xia, X., Chen, H., Goloub, P., Zong, X., Zhang, W., and Wang, P.: Climatological aspects of aerosol opticalproperties in North China Plain based on ground and satellite remote-sensing data, J. Quant. Spectrosc. Ra., 127, 12-23, 2013.

Xia, X., Che, H., Zhu, J., Chen, H., Cong, Z., Deng, X., Fan, X., Fu, Y., Goloub, P., Jiang, H., Liu, Q., Mai, B., Wang, P., Wu, Y., Zhang, J., Zhang, R., and Zhang, X.: Ground-based remote sensing of aerosol climatology in China: Aerosol optical properties, direct radiative effect and its parameterization, Atmos. Environ., 124, 243-251, https://doi.org/10.1016/j.atmosenv.2015.05.071, 2016.

Xie, Y., Zhang, Y., Xiong, X. X, Qu, J. J., and Che, H. Z.: Validation of MODIS aerosol optical depth product over China using CARSNET measurements, Atmos. Environ., 45, 5970-5978, 2011.

Xin, J., Wang, Y., Li, Z., Wang, P., Hao, W., Nordgren, B., Wang, S., Liu, G., Wang, L., Wen, T., Sun, Y., and Hu, B.: Aerosoloptical depth (AOD) and angstrom exponent of aerosols observed by the Chinese Sun Hazemeter Networkfrom August 2004 to September 2005, J. Geophys. Res., 112, D05203, https://doi.org/10.1029/2006JD007075, 2007.

Xin, J. Y., Zhang, Q., Gong, C. S., Wang, Y. S., Du, W. P., and Zhao, Y. F.: Aerosol direct radiative forcing over Shandong Peninsula in East Asia from 2004 to 2011, Atmos. Ocean. Sci. Lett., 7, 7479, 2014.

$\mathrm{Xu}, \mathrm{X}$. and Wang, J.: Retrieval of aerosol microphysical properties from AERONET photopolarimetric measurements: 1. Information content analysis, J. Geophys. Res.-Atmos., 120, 7059-7078, https://doi.org/10.1002/2015JD023108, 2015.

Xu, X., Wang, J., Zeng, J., Spurr, R., Liu, X., Dubovik, D., Li, L., Li, Z., Mishchenko, M. I., Siniuk, A., and Holben, B. N.: Retrieval of aerosol microphysical properties from AERONET photopolarimetric measurements: 2. A new research algorithm and 
case demonstration, J. Geophys. Res.-Atmos., 120, 7079-7098, https://doi.org/10.1002/2015JD023113, 2015.

Yang, M., Howell, S. G., Zhuang, J., and Huebert, B. J.: Attribution of aerosol light absorption to black carbon, brown carbon, and dust in China - interpretations of atmospheric measurements during EAST-AIRE, Atmos. Chem. Phys., 9, 2035-2050, https://doi.org/10.5194/acp-9-2035-2009, 2009.

Zhang, L., Sun, J. Y., Shen, X. J., Zhang, Y. M., Che, H., Ma, Q. L., Zhang, Y. W., Zhang, X. Y., and Ogren, J. A.: Observations of relative humidity effects on aerosol light scattering in the Yangtze River Delta of China, Atmos. Chem. Phys., 15, 84398454, https://doi.org/10.5194/acp-15-8439-2015, 2015.

Zhang, Q., Streets, D. G., Carmichael, G. R., He, K. B., Huo, H., Kannari, A., Klimont, Z., Park, I. S., Reddy, S., Fu, J. S., Chen, D., Duan, L., Lei, Y., Wang, L. T., and Yao, Z. L.: Asian emissions in 2006 for the NASA INTEX-B mission, Atmos. Chem. Phys., 9, 5131-5153, https://doi.org/10.5194/acp-9-5131-2009, 2009.

Zhang, X. Y., Wang, Y. Q., Niu, T., Zhang, X. C., Gong, S. L., Zhang, Y. M., and Sun, J. Y.: Atmospheric aerosol compositions in China: spatial/temporal variability, chemical signature, regional haze distribution and comparisons with global aerosols, Atmos. Chem. Phys., 12, 779-799, https://doi.org/10.5194/acp12-779-2012, 2012.

Zhao, H., Che, H., Zhang, X., Ma, Y., Wang, Y., Wang, X., Liu, C., Hou, B., and Che, H.: Aerosol optical properties over urban and industrial region of Northeast China by using ground-based sunphotometer measurement, Atmos. Environ., 75, 270-278, 2013.
Zhao, H., Che, H., Ma, Y., Xia, X., Wang, Y., Wang, P., and Wu, $\mathrm{X}$. : Temporal variability of the visibility, particulate matter mass concentration and aerosol optical properties over an urban site in Northeast China, Atmos. Res., 166, 204-212, 2015.

Zheng, C., Zhao, C., Zhu, Y., Wang, Y., Shi, X., Wu, X., Chen, T., Wu, F., and Qiu, Y.: Analysis of influential factors for the relationship between $\mathrm{PM}_{2.5}$ and AOD in Beijing, Atmos. Chem. Phys., 17, 13473-13489, https://doi.org/10.5194/acp-17-134732017, 2017.

Zhu, J., Che, H., Xia, X., Chen, H. B., Goloub, P., and Zhang, W. Column-integrated aerosol optical and physical properties at a regional background atmosphere in North China Plain, Atmos. Environ., 84, 54-64, 2014.

Zhuang, B., Wang, T., Li, S., Liu, J., Talbot, R., Mao, H., Yang, X., Fu, C., Yin, C., Zhu, J., Che, H., and Zhang, X.: Optical properties and radiative forcing of urban aerosols in Nanjing over China, Atmos. Environ., 83, 43-52, 2014.

Zhuang, B., Wang, T., Liu, J., Che, H., Han, Y., Fu, Y., Li, S., Xie, M., Li, M., Chen, P., Chen, H., Yang, X.-Q., and Sun, J.: The optical, physical properties and direct radiative forcing of urban columnar aerosols in Yangtze River Delta, China, Atmos. Chem. Phys. Discuss., https://doi.org/10.5194/acp-2017-215, in review, 2017. 